Article

\title{
Synthesis and Anti-Hepatocarcinoma Effect of Amino Acid Derivatives of Pyxinol and Ocotillol
}

\author{
Ying Zhang ${ }^{1,2}$, Hui Yu ${ }^{1}$, Shuzheng Fu ${ }^{1}$, Luying Tan ${ }^{1}$, Junli Liu ${ }^{1}$, Baisong Zhou ${ }^{1}$, Le Li ${ }^{1}$, Yunhe Liu ${ }^{1}$, \\ Caixia Wang ${ }^{1}$, Pingya $\mathrm{Li}^{1}$ and Jinping Liu ${ }^{1,3, * \mathbb{C}}$ \\ 1 School of Pharmaceutical Sciences, Jilin University, Fujin Road 1266, Changchun 130021, China; \\ zhangying17@mails.jlu.edu.cn (Y.Z.); yuhui19@mails.jlu.edu.cn (H.Y.); fusz19@mails.jlu.edu.cn (S.F.); \\ tanly20@mails.jlu.edu.cn (L.T.); junli18@mails.jlu.edu.cn (J.L.); bszhou19@mails.jlu.edu.cn (B.Z.); \\ lile19@mails.jlu.edu.cn (L.L.); yunhe20@mails.jlu.edu.cn (Y.L.); cxwang20@mails.jlu.edu.cn (C.W.); \\ lipy@jlu.edu.cn (P.L.) \\ 2 The First Hospital of Jilin University, Changchun 130021, China \\ 3 Research Center of Natural Drug, Jilin University, Changchun 130021, China \\ * Correspondence: liujp@jlu.edu.cn
}

Citation: Zhang, Y.; Yu, H.; Fu, S.; Tan, L.; Liu, J.; Zhou, B.; Li, L.; Liu, Y.; Wang, C.; Li, P.; et al. Synthesis and Anti-Hepatocarcinoma Effect of Amino Acid Derivatives of Pyxinol and Ocotillol. Molecules 2021, 26, 780. https://doi.org/10.3390/ molecules 26040780

Received: 5 January 2021

Accepted: 30 January 2021

Published: 3 February 2021

Publisher's Note: MDPI stays neutral with regard to jurisdictional claims in published maps and institutional affiliations.

Copyright: (c) 2021 by the authors. Licensee MDPI, Basel, Switzerland. This article is an open access article distributed under the terms and conditions of the Creative Commons Attribution (CC BY) license (https:/ / creativecommons.org/licenses/by/ $4.0 /)$.

\begin{abstract}
Aiming at seeking an effective anti-hepatocarcinoma drug with low toxicity, a total of 24 amino acid derivatives (20 new along with 4 known derivatives) of two active ocotillol-type sapogenins (pyxinol and ocotillol) were synthesized. Both in vitro and in vivo anti-hepatocarcinoma effects of derivatives were evaluated. At first, the HepG2 human cancer cell was employed to evaluate the anti-cancer activity. Most of the derivatives showed obvious enhanced activity compared with pyxinol or ocotillol. Among them, compound $2 \mathbf{e}$ displayed the most excellent activity with an $\mathrm{IC}_{50}$ value of $11.26 \pm 0.43 \mu \mathrm{M}$. Next, H22 hepatoma-bearing mice were used to further evaluate the anti-liver cancer activity of compound 2 e. It was revealed that the growth of $\mathrm{H} 22$ transplanted tumor was significantly inhibited when treated with compound $\mathbf{2 e}$ or compound $\mathbf{2 e}$ combined with cyclophosphamide (CTX) $(p<0.05, p<0.01)$, and the inhibition rates of tumor growth were $35.32 \%$ and $55.30 \%$, respectively. More importantly, compound $\mathbf{2 e}$ caused limited damage to liver and kidney in contrast with CTX causing significant toxicity. Finally, the latent mechanism of compound $2 \mathbf{e}$ was explored by serum and liver metabolomics based on ultra-performance liquid chromatography quadrupole time-of-flight mass spectrometry (UPLC-QTOF-MS) technology. A total of 21 potential metabolites involved in 8 pathways were identified. These results suggest that compound $\mathbf{2} \mathbf{e}$ is a promising agent for anti-hepato-carcinoma, and that it also could be used in combination with CTX to increase efficiency and to reduce toxicity.
\end{abstract}

Keywords: pyxinol; ocotillol; amino acid derivatives; anti-hepatocarcinoma; metabolomics

\section{Introduction}

Liver cancer, the fourth major lethal malignancy worldwide, is generally divided into HCC (hepatocellular carcinoma), ICC (intrahepatic cholangiocarcinoma) and MHC (mixed hepato- cellular and cholangiocellular carcinoma) based on the pathological classification [1]. HCC, with 5-year overall survival, is only $10 \%$, yet accounts for nearly $75 \%$ to $85 \%$ of liver cancer cases [2,3]. Despite the enormous efforts such as surgery, chemotherapy, radiation therapy, immunotherapy, and monoclonal antibody therapy to combat liver cancer, the disease burden imposed by it continues to increase [4]. Numerous scientific researchers devoted themselves to the modification or transformation of lead compounds with the purpose of obtaining derivative products with good properties [5-8]. Natural products and their structurally modified derivatives have been widely used as anti-tumor drugs due to the low toxicity and the ability of reversing multidrug resistance [9-12].

Ocotillol-type saponins or sapogenins, with a tetrahydrofuran ring in side chain, are the natural triterpenoids [13,14]. Pyxinol and ocotillol are two important sapogenins [11]. Pyxinol 
(CAS number: 25330-18-1) was isolated from some natural plants such as Pyxine endochrysina $\mathrm{N}_{\mathrm{YL}}$, Notholaena rigidain, Salvia barrelieri and Betula humilis, respectively [15-18]. Interestingly, pyxinol is also the active metabolite of protopanaxadiol (the main aglycon of ginsenosides) in human liver [19]. It was reported that pyxinol exhibited multiple pharmacological activities such as anti-cancer (including lung carcinoma, cervical carcinoma and colonic adenocarcinoma) [20-22], anti-multidrug resistance [11] and anti-inflammatory [23], etc. Ocotillol (CAS number: 5986-39-0)—firstly discovered from Panax pseudoginseng Subsp. Himalaicus collected in Eastern Himalaya [24] —was also the main metabolite of ginsenosides in American ginseng [25]. Ocotillol had the effects of anti-ovarian cancer, anti-liver cancer [26-29], anti-inflammatory [30], anti-bacterial [31], etc. Our team have successfully prepared pyxinol and ocotillol with high yields by treating various ginsenosides [32]. However, in the continuing study, we found that pyxinol and ocotillol both had the unsatisfactory properties that limited their application and development. Pyxinol, with the low oral bioavailability and short $t_{1 / 2}$ in rats [33], showed weaker activities (such as anti-heart failure, anti-inflammatory and anti-bacterial) than its derivatives in vitro and in vivo $[23,31,34]$. Ocotillol, with low water solubility [35] and high plasma protein binding rates [36], had the low systemic exposure, poor absorption into blood and long $t_{1 / 2}$ in rats [37]. Therefore, it is necessary to modify pyxinol and ocotillol into derivatives with better properties and better pharmacological activity. The introduction of amino acid groups in the structure could improve the solubility, enhance active transport, promote intestinal absorption, reduce side effects and improve bioavailability of natural products [38]. From all the above facts, we anticipated that amino acid conjugated ocotillol-type sapogenin might result in new leads possessing good pharmacological activities.

According to the reports, the properties or the activities of lead compounds could be improved by amino acid groups [39-45], and the research about the triterpenoids conjugated with amino acids has made good progress. Pyxinol or 24S-pyxinol conjugated with amino acids showed better antibacterial or better anti-inflammatory activities [46]. The amino acid derivatives of 25-OCH3/OH-Protopanaxadiol showed higher anti-tumor activity [47]. In addition, it was reported that the anti-liver tumor activity could be significantly improved by conjugating sapogenin AD-1 with amino acids [48]. Amino acids are also closely related to the reduction in the incidence of HCC in patients with liver cirrhosis $[49,50]$. Moreover, as an important auxiliary treatment method for the improvement of hepatopathy, appropriate supplementation of amino acids have attracted more and more attention [51].

The present study designed and synthesized a series of amino acid derivatives of pyxinol and ocotillol. HepG2 cell line was then employed to evaluate the anti-cancer activity of all the derivatives. $\mathrm{H} 22$ hepatoma-bearing mice were furtherly used to evaluate the activity of potential anti-tumor agent. The ultra-performance liquid chromatography quadrupole time-of-flight mass spectrometry (UPLC-QTOF-MS) based metabolomics approach, a burgeoning omics technique by measuring the dynamic multiparametric metabolic response of the living system, was finally applied to explore the latent mechanism of the active derivative.

\section{Results and Discussion}

\subsection{Design}

As for the structure of ocotillol-type sapogenins, $3-\mathrm{OH}$ is relatively far from other hydrogen donor or acceptor atoms and dominates an important place in the metabolic pathway. According to the previous literature, $3-\mathrm{OH}$ was suitable for modification to improve the activity without affecting other potential binding sites [52,53]. Many efforts and progress had been made in modifying 3-OH of ocotillol-type sapogenins. The substitution at C-3 hydroxy such as the oxidation products [54], aromatic carboxylate derivatives [55], alkylation products [56], nitrate derivatives [20], amino acid derivatives [28], bromoalkanoates derivatives [20], oxime derivatives [53] and N-substituted amide derivatives [57] 
could all significantly enhance the biological activity of ocotillol-type sapogenins. Therefore, 3-OH was selected for further modification [19] in our study.

Amino acid imbalance is related to the liver diseases. For examples: the level of alanine (Ala) was found to be significantly reduced in cirrhotic rats, [58]; the levels of leucine (Leu) and valine (Val) were also clarified to decrease in patients with liver cirrhosis [50,59]; glycine (Gly) could alleviate liver injury in rats through its antioxidant properties [60]; methionine (Met) plays a key role in many cellular functions, deficiency of Met in rats could induce liver injury [60]; proline (Pro) could scavenge free radicals and reduce tissue damage in patients with liver cirrhosis [61]. What is more, the amino acids that make up natural proteins are all L-type, which is more prone to proteolysis. So, in the present study, the typical aliphatic amino acids (Ala, Leu, Val, Gly and Met) and heterocyclic amino acid (Pro) were chosen to modify pyxinol and ocotillol (Figure 1).

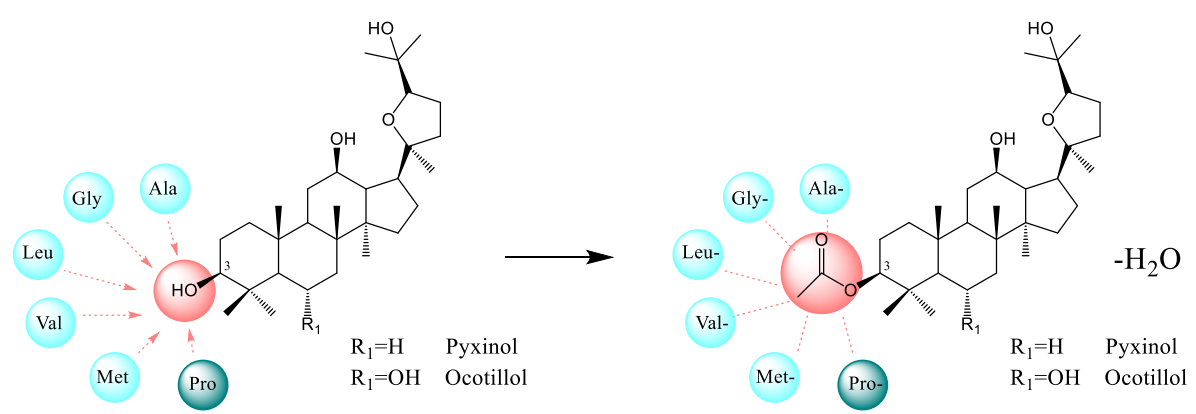

Figure 1. Design of amino acid derivatives of ocotillol-type sapogenins.

\subsection{Chemistry}

A total of 24 amino acid derivatives of pyxinol and ocotillol were synthesized as shown in Figure 2. Compounds 1a-1f and $\mathbf{3 a}-\mathbf{3 f}$ were separately synthesized by pyxinol and ocotillol in the presence of EDC \{1-ethyl-3-(3-dimethylaminopropyl) carbodiimide $\}$ and DMAP (4-dimethylamino- pyridine) mediated esterifications of N-Boc protected amino acids in dry $\mathrm{CH}_{2} \mathrm{Cl}_{2}$ or THF (tetra- hydrofuran) at room temperature. The tert-butyl carbonate groups of them were removed in a mixed solvent of dry $\mathrm{CH}_{2} \mathrm{Cl}_{2}$ and TFA (trifluoroacetic acid) at room temperature to obtain compounds $\mathbf{2 a - 2 f}$ and $\mathbf{4 a}-\mathbf{4 f}$. Silica gel column chromatography was used for purification of all the derivatives from the reaction mixture, and the structures of all products were confirmed by ${ }^{1} \mathrm{H}-\mathrm{NMR},{ }^{13} \mathrm{C}-\mathrm{NMR}$ and HR-MS. Taking compound $\mathbf{2 e}$ as an example, its molecular formula was established as $\mathrm{C}_{35} \mathrm{H}_{59} \mathrm{NO}_{5}$ by HR-ESI-MS. Compared with pyxinol $\left(\mathrm{C}_{30} \mathrm{H}_{52} \mathrm{O}_{4}\right.$, the lead compound), compound $2 \mathbf{e}$ has an increased part $\left(\mathrm{C}_{5} \mathrm{H}_{7} \mathrm{NO}\right.$, equivalent to the deshydroxyproline). The ${ }^{1} \mathrm{H}-\mathrm{NMR}\left(\mathrm{CDCl}_{3}, 600 \mathrm{MHz}\right)$ spectrum of compound $2 \mathbf{e}$ showed eight methyl singlet signals at $\delta_{\mathrm{H}} 1.25,1.24,1.08,0.96,0.88,0.86,0.84,0.81$; also showed the hydrogen singlet signal at $\delta_{\mathrm{H}} 3.96$, which was attached to the $\alpha$-carbon of proline. The ${ }^{13} \mathrm{C}-\mathrm{NMR}$ spectrum of compound $2 \mathbf{e}$ showed 35 carbon signals in total. A carbonyl carbon signal was also shown at $\delta_{\mathrm{C}} 173.27$, indicating the presence of an ester bond. The chemical shifts of C-3 moved to low-field region compared with pyxinol, demonstrating proline was conjugated at $\mathrm{C}-3$ of

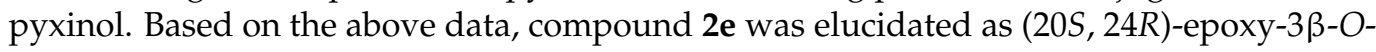
(1-prolyl)-dammarane-12 $\beta$, 25-diol. Compounds $\mathbf{2 a}, \mathbf{2 c}$, $\mathbf{2} \mathbf{d}$ and $\mathbf{2 f}$ were prepared according to the published literature [31]. The other 20 derivatives are the new compounds. 

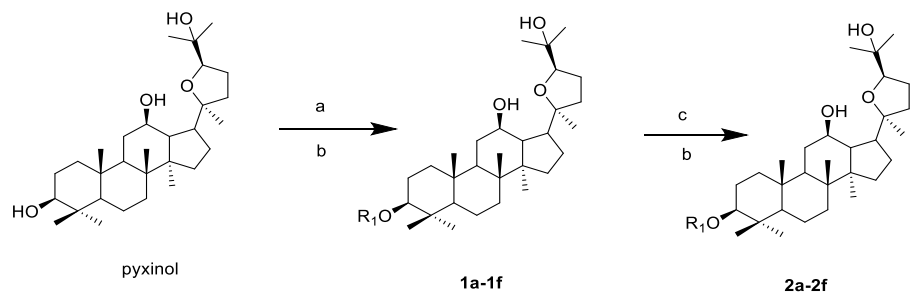
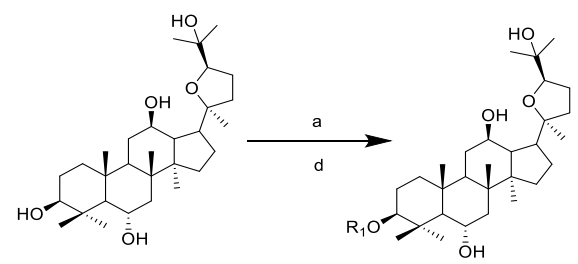

3a-3f
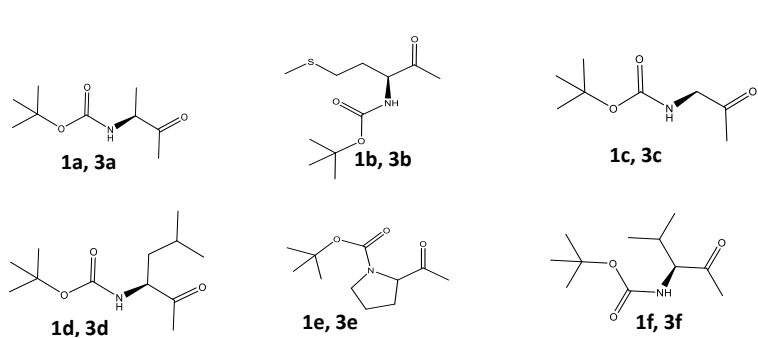

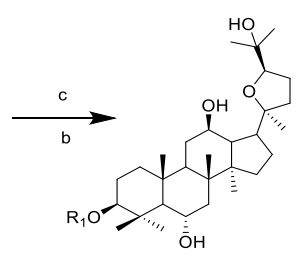

4a-4f

Figure 2. Synthesis of pyxinol and ocotillol derivatives 1a-1f, 2a-2f, 3a-3f, 4a-4f. Reagents and conditions: (a) DMAP, EDC, boc-amino acid, r.t. (b) dry $\mathrm{CH}_{2} \mathrm{Cl}_{2}$, r.t. (c) TFA, r.t. (d)THF, r.t.

\subsection{Cytotoxic Activity Determination on HepG2 Cells}

All compounds including lead compounds (pyxinol and ocotillol) and derivatives were evaluated for their cytotoxic activity against the HepG2 cell line by using the CCK-8 assay method with cyclophosphamide (CTX) as the positive control. The results revealed that most derivatives, such as $\mathbf{1 a}, \mathbf{1 c}, \mathbf{1 e}, \mathbf{2 a}-\mathbf{2 f}, \mathbf{3 c}, \mathbf{3 e}$ and $\mathbf{4 a - 4 f}$, could enhance the antitumor activity of lead compounds. In particular, compound $\mathbf{2 e}$ exhibited the highest inhibitory effect on HepG2 cells in vitro with $\mathrm{IC}_{50}$ similar to the positive drug (Table 1). Therefore, compound 2e, the most potent growth inhibitor of the HepG2 cells, was selected for further study.

Table 1. $\mathrm{IC}_{50}(\mu \mathrm{M})$ of all compounds over HepG2 cells.

\begin{tabular}{cccc}
\hline Compounds & IC $_{\mathbf{5 0}}(\boldsymbol{\mu M})$ & Compounds & IC $_{\mathbf{5 0}}(\boldsymbol{\mu M})$ \\
\hline Pyxinol & $74.49 \pm 1.09$ & Ocotillol & $92.65 \pm 3.07$ \\
$\mathbf{1 a}$ & $26.33 \pm 0.72$ & $\mathbf{3 a}$ & $60.95 \pm 1.57$ \\
$\mathbf{1 b}$ & $73.55 \pm 2.60$ & $\mathbf{3 b}$ & $88.60 \pm 5.03$ \\
$\mathbf{1 c}$ & $26.63 \pm 1.52$ & $\mathbf{3 c}$ & $32.62 \pm 1.55$ \\
$\mathbf{1 d}$ & $73.14 \pm 1.67$ & $\mathbf{3 d}$ & $74.91 \pm 2.87$ \\
$\mathbf{1 e}$ & $30.46 \pm 2.98$ & $\mathbf{3 e}$ & $41.75 \pm 2.58$ \\
$\mathbf{1 f}$ & $62.15 \pm 3.78$ & $\mathbf{3 f}$ & $80.10 \pm 2.03$ \\
$\mathbf{2 a}$ & $16.46 \pm 1.66$ & $\mathbf{4 a}$ & $33.99 \pm 0.90$ \\
$\mathbf{2 b}$ & $20.29 \pm 2.04$ & $\mathbf{4 b}$ & $50.65 \pm 0.62$ \\
$\mathbf{2 c}$ & $16.31 \pm 0.31$ & $\mathbf{4 c}$ & $20.55 \pm 2.47$ \\
$\mathbf{2 d}$ & $20.13 \pm 3.49$ & $\mathbf{4 d}$ & $35.44 \pm 1.59$ \\
$\mathbf{2 e}$ & $11.26 \pm 0.43$ & $\mathbf{4 e}$ & $24.62 \pm 0.35$ \\
$\mathbf{2 f}$ & $19.74 \pm 1.96$ & $\mathbf{4 f}$ & $44.74 \pm 3.07$ \\
\hline
\end{tabular}




\subsection{Effects of Compound 2e on H22 Tumor-Bearing Mice}

2.4.1. Effect on Body Weight, Tumor Weight, Tumor Volume and Organ Indexes

Body weights, tumor weights, liver index and kidney index are presented in Table 2. Tumor volume is shown in Figure 3. There is no significant difference in body weights of mice between the groups.

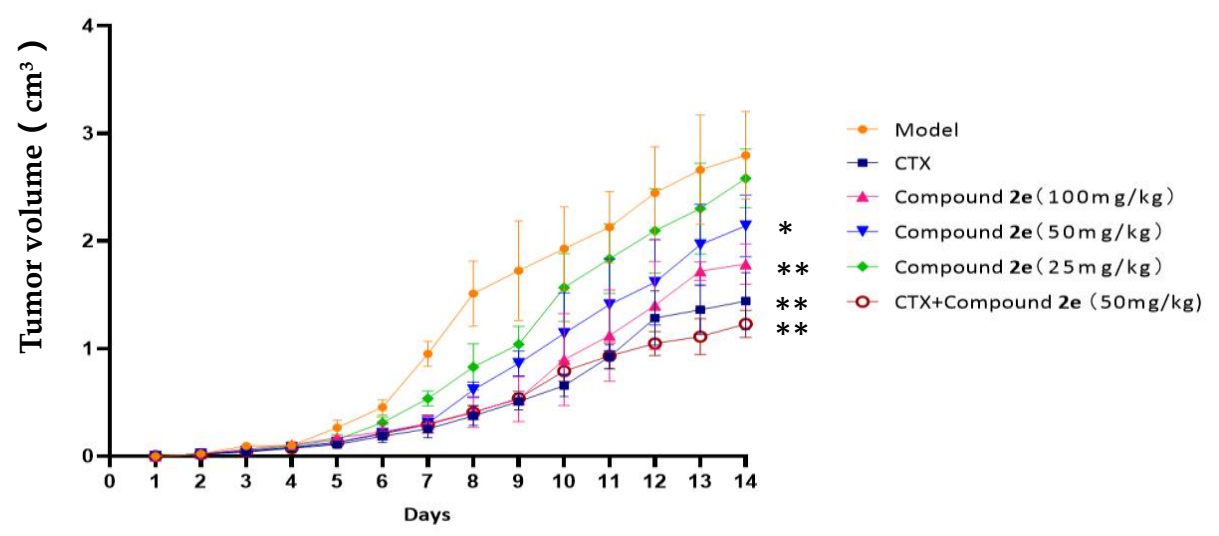

Figure 3. Effect on tumor volume. Compared with the model group, ${ }^{*} p<0.05,{ }^{* *} p<0.01$.

Tumors of the model group reached $10-18 \mathrm{~mm}$ in diameter on day 14 . While CTX, compound $\mathbf{2 e}$ and compound $\mathbf{2 e}+\mathrm{CTX}$ treatment resulted in delayed tumor growth compared with model group. It was showed that compound $2 \mathbf{2 e}$ groups $(50,100 \mathrm{mg} / \mathrm{kg}$ ) could significantly reduce the tumor weight and volume compared to the model group $(p<0.05, p<0.01)$. Treatment with compound 2e could decrease the tumor weight and increase the tumor inhibition rate (TIR) in a dose- dependent manner. Both CTX group and compound $2 \mathbf{e}+\mathrm{CTX}$ group could significantly reduce tumor weights and volumes compared to the model group $(p<0.01)$. Compound $\mathbf{2 e}+\mathrm{CTX}$ group displayed the highest $\operatorname{TIR}(55.30 \%)$.

The data also showed that the liver and kidney indexes were significantly increased in the model group compared with the normal group $(p<0.01)$. While the indexes of compound 2e-treated mice were basically consistent with the model group. However, the compound 2e + CTX group, which displayed similar indexes to the normal group, could significantly decreased the liver $(p<0.01)$ and kidney $(p<0.05)$ indexes compared with model group.

\subsubsection{Histopathological Examination}

Histological analyses of tumors, liver and kidney using H\&E staining are shown in Figure 4.

The tumor cells in the model group showed aggressive growth in different forms and sizes. Mitotic activity and different stained tumor cells were also detected. The necrosis in the CTX group was more obvious than in the compound 2e high-dose group, but had extensive necrosis in the compound $\mathbf{2} \mathbf{e}+\mathrm{CTX}$ group.

The liver and kidney cells in the model group and CTX group had many vacuoles and edema. This phenomenon had been alleviated in compound $\mathbf{2 e}$ high-dose group and in compound $2 \mathbf{e}+$ CTX group. 
Table 2. Effects on body weight, tumor weight and organ indexes.

\begin{tabular}{|c|c|c|c|c|c|c|c|c|}
\hline \multirow{2}{*}{ Groups } & \multirow{2}{*}{ Dosages (mg/kg) } & \multicolumn{2}{|c|}{ BODYWEIGHT (g) } & \multirow{2}{*}{$\begin{array}{c}\text { Increase of Body } \\
\text { Weight } \\
\text { (g) }\end{array}$} & \multirow{2}{*}{$\begin{array}{c}\text { Tumor Weight } \\
\text { (g) }\end{array}$} & \multirow{2}{*}{$\begin{array}{c}\text { Inhibitory Rate } \\
(\%)\end{array}$} & \multirow{2}{*}{ Liver Index(mg/g) } & \multirow{2}{*}{$\begin{array}{l}\text { Kidney Index } \\
(\mathrm{mg} / \mathrm{g})\end{array}$} \\
\hline & & D1 & D14 & & & & & \\
\hline Normal & - & $22.35 \pm 1.58$ & $36.59 \pm 3.63$ & $14.24 \pm 2.61$ & - & - & $37.99 \pm 6.03$ & $11.08 \pm 1.72$ \\
\hline Model & - & $21.24 \pm 1.66$ & $35.86 \pm 3.53$ & $14.62 \pm 3.49$ & $1.61 \pm 0.35$ & - & $45.69 \pm 6.19$ & $13.89 \pm 2.24$ \\
\hline CTX & 20 & $21.20 \pm 1.71$ & $32.76 \pm 3.14$ & $11.56 \pm 3.23$ & $0.81 \pm 0.18^{* *}$ & $49.69 \%$ & $51.54 \pm 7.69$ & $13.27 \pm 1.96$ \\
\hline \multirow{2}{*}{ Compound 2e } & 25 & $23.12 \pm 2.18$ & $35.27 \pm 3.18$ & $12.15 \pm 3.71$ & $1.35 \pm 0.26$ & $16.20 \%$ & $42.89 \pm 6.04$ & $12.24 \pm 1.92$ \\
\hline & 100 & $22.51 \pm 1.70$ & $35.64 \pm 2.89$ & $13.13 \pm 3.36$ & $1.04 \pm 0.23^{* *}$ & $35.32 \%$ & $41.83 \pm 4.31$ & $12.42 \pm 1.21$ \\
\hline $\mathbf{2 e}+\mathrm{CTX}$ & $50+20$ & $23.07 \pm 2.29$ & $37.65 \pm 3.70$ & $14.58 \pm 2.68$ & $0.72 \pm 0.20 * *$ & $55.30 \%$ & $37.01 \pm 4.47^{* *}$ & $11.72 \pm 2.24$ * \\
\hline
\end{tabular}

Compared with the model group, ${ }^{*} p<0.05,{ }^{* *} p<0.01$. Mice were intragastrically administered once a day continuously for 14 days. 

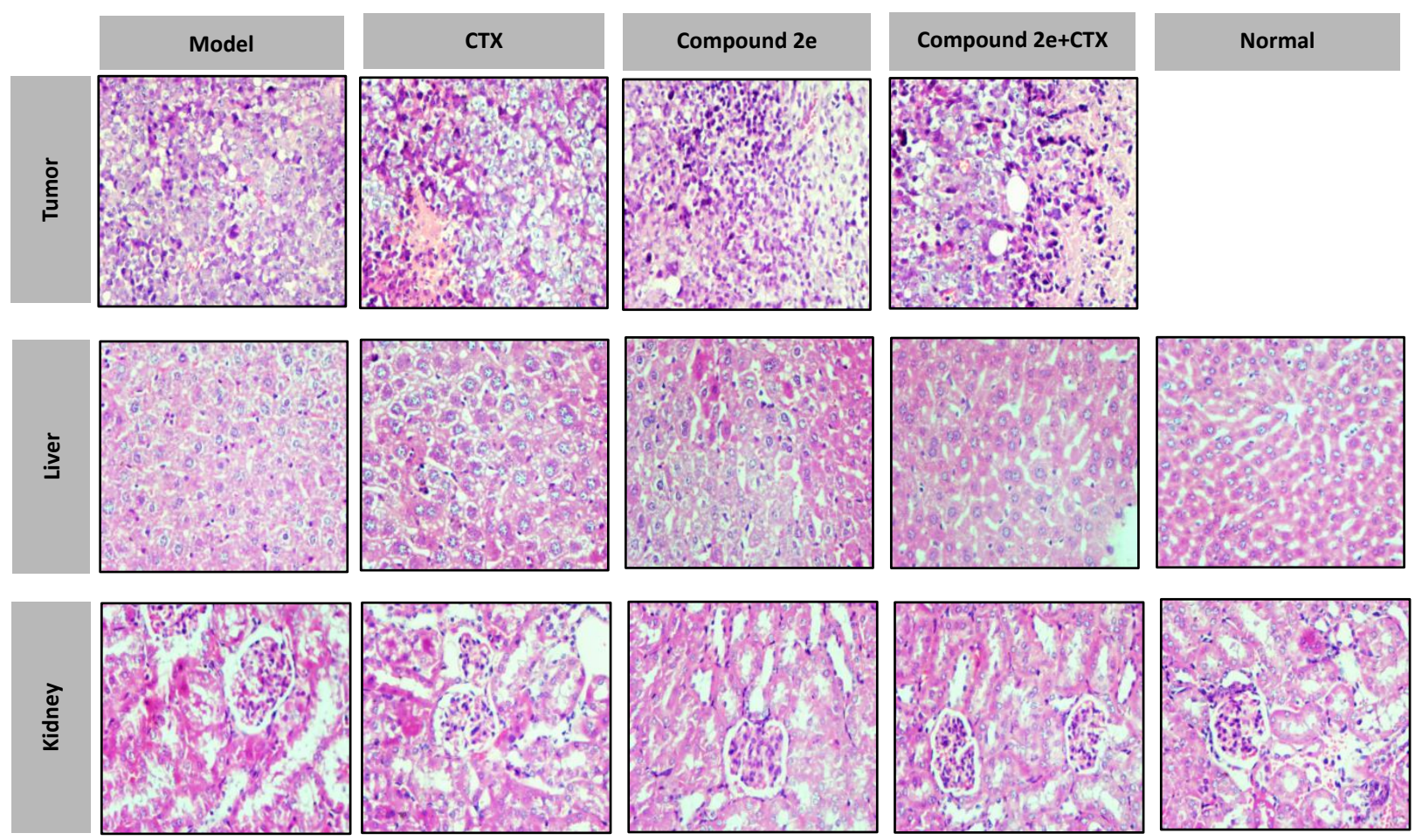

Figure 4. Histological examination of morphological changes in tumor, liver and kidney.

\subsubsection{Effects of Compound 2e Treatment on Cytokine Levels in Mice}

The effects of compound $2 \mathbf{e}$ treatment on the expression of IL-2 (Interleukin-2), TNF- $\alpha$ (Tumor necrosis factor- $\alpha$ ) and VEGF (Vascular endothelial growth factor) were listed in Table 3. The level of TNF- $\alpha$ and IL-2 were greatly reduced after CTX treatment compared with the normal group $(p<0.01)$, which indicated that the immune system was suppressed by CTX. The level of TNF- $\alpha$ was dose-dependently increased in compound $2 \mathbf{e}$ treatment groups compared to the model group, and the highest level was observed in high-dose compound $\mathbf{2 e}$ group. These data indicated that compound $\mathbf{2 e}$ might enhance immune function in $\mathrm{H} 22$ tumor-bearing mice by increasing cytokine levels. The levels of IL-2 in compound 2e groups (moderate and high-dose) were significantly elevated compared to model group $(p<0.01)$, and they were also dose-dependently increased. These results showed that the proliferation and activation of $\mathrm{T}$ lymphocytes might be stimulated to cause tumor cell death. Meanwhile, the levels of VEGF expression in compound 2e treatment groups were all significantly decreased in a dose-dependent manner compared with the model group. CTX and compound $\mathbf{2 e}$ (moderate and high dose) could significantly inhibit the VEGF level in serum $(p<0.01)$. It was indicated that compound $2 \mathbf{e}$ might inhibit tumor growth by effectively reducing tumor angiogenesis.

\subsubsection{Effects of Compound 2e Treatment on Hepatic and Renal Function}

The results listed in Table 4 indicated that the serum AST (Aspartate aminotransferase), ALT (Alanine aminotransferase), CRE (Creatinine) and BUN (Blood urea nitrogen) levels dramatically increased in the model group compared with the normal group. The increased levels could be significantly re-regulated with the treatment of compound $2 \mathbf{e}(p<0.01)$ or CTX $(p<0.01)$. The high dosage of compound 2e showed the best effect. Moreover, the combination group showed the lower values than those in CTX group, which indicated that compound 2e could increase CTX's efficiency and reduce its toxicity. These results implied that compound $\mathbf{2 e}$ did less harm to the liver and kidney of tumor-bearing mouse. 
Table 3. Effects of compound $\mathbf{2 e}$ on cytokine levels (mean $\pm \mathrm{SD}, n=6$ ) in $\mathrm{H} 22$ tumor-bearing mice.

\begin{tabular}{ccccc}
\hline Groups & $\begin{array}{c}\text { Dosages } \\
(\mathbf{m g} / \mathbf{k g})\end{array}$ & $\begin{array}{c}\text { TNF- } \boldsymbol{\alpha} \\
(\mathbf{p g} / \mathbf{m L})\end{array}$ & $\begin{array}{c}\text { IL-2 } \\
(\mathbf{p g} / \mathbf{m L})\end{array}$ & $\begin{array}{c}\text { VEGF } \\
(\mathbf{p g} / \mathbf{m L})\end{array}$ \\
\hline Normal & - & $306.77 \pm 17.47$ & $150.93 \pm 6.01$ & $97.76 \pm 13.75$ \\
\hline Model & - & $388.35 \pm 28.22^{\# \#}$ & $95.81 \pm 16.50^{\# \#}$ & $188.94 \pm 22.43^{\# \#}$ \\
\hline CTX & 20 & $207.47 \pm 23.37^{\# \#, * *}$ & $110.52 \pm 17.54^{\# \#}$ & $103.43 \pm 14.00^{* *}$ \\
\hline Compound 2e & 25 & $287.01 \pm 39.10^{* *}$ & $111.13 \pm 13.28^{\# \#}$ & $158.32 \pm 15.97^{\# \#, *}$ \\
\cline { 2 - 5 } & 50 & $321.97 \pm 55.57^{*}$ & $136.86 \pm 22.66^{* *}$ & $127.62 \pm 17.46^{\# \#, * *}$ \\
\hline 2e + CTX & 100 & $358.35 \pm 45.19^{\#}$ & $174.11 \pm 28.90^{* *}$ & $114.67 \pm 15.42^{* *}$ \\
\hline
\end{tabular}

Compared with the normal control group, ${ }^{\#} p<0.05,{ }^{\# \#} p<0.01$; Compared with the model group, ${ }^{*} p<0.05,{ }^{* *} p<0.01$.

Table 4. Effects of compound 2e treatment on hepatic and renal function.

\begin{tabular}{cccccc}
\hline Groups & $\begin{array}{c}\text { Dosages } \\
(\mathbf{m g} / \mathbf{k g})\end{array}$ & $\begin{array}{c}\text { ALT } \\
(\mathbf{I U} / \mathrm{L})\end{array}$ & $\begin{array}{c}\text { AST } \\
(\mathbf{I U} / \mathrm{L})\end{array}$ & $\begin{array}{c}\text { CRE } \\
(\mu \mathrm{mol} / \mathbf{L})\end{array}$ & $\begin{array}{c}\text { BUN } \\
(\mathbf{m m o l} / \mathbf{L})\end{array}$ \\
\hline Normal & - & $19.48 \pm 2.36$ & $24.78 \pm 3.38^{* *}$ & $20.71 \pm 7.77$ & $9.09 \pm 1.81$ \\
\hline Model & - & $73.60 \pm 2.76^{\# \#, * *}$ & $91.8 \pm 6.62^{\# \#, * *}$ & $41.89 \pm 10.27^{\# \#}$ & $20.75 \pm 4.96^{\# \#}$ \\
\hline CTX & 20 & $50.61 \pm 3.22^{\# \#, * *}$ & $53.47 \pm 5.04^{\# \#, * *}$ & $32.86 \pm 7.74^{\#}$ & $14.23 \pm 2.38^{\# \#, *}$ \\
\hline Compound 2e & 25 & $43.62 \pm 5.15^{\# \#, * *}$ & $42.51 \pm 5.22^{\# \#, * *}$ & $31.17 \pm 9.03$ & $12.70 \pm 2.24^{\#, * *}$ \\
\cline { 2 - 6 } & 50 & $42.31 \pm 5.00^{\# \#, * *}$ & $38.69 \pm 6.43^{\# \#, * *}$ & $28.95 \pm 9.16^{*}$ & $11.06 \pm 2.16^{* *}$ \\
\hline 2e + CTX & 100 & $35.37 \pm 3.32^{\# \#, * *}$ & $31.47 \pm 4.48^{\#, * *}$ & $26.93 \pm 10.60^{*}$ & $10.32 \pm 2.77^{* * *}$ \\
\hline
\end{tabular}

Compared with the normal control group, ${ }^{\#} p<0.05,{ }^{\# \#} p<0.01$; Compared with the model group, ${ }^{*} p<0.05,{ }^{* *} p<0.01$.

\subsection{Metabolomics Study}

\subsubsection{Validation of UPLC-QTOF-MS}

UPLC-QTOF-MS system was used to perform the metabolomic study. The validation test was first conducted to monitor the durability and stability of system. Serum and liver quality control (QC) samples were run randomly covering the whole analysis process, respectively. The tests included: (1) five consecutive serum or liver QC samples were detected to evaluate the injection precision; (2) five parallel replicates of a serum or liver test sample were assayed to assess the reproducibility; (3) the post-preparation stability of the sample was estimated by detecting one serum or liver test sample that was placed in the autosampler at $10{ }^{\circ} \mathrm{C}$ for $0,2,8,12$, and $24 \mathrm{~h}$. In the above test, the exact mass/retention time pairs of eight ions in serum or in liver QC samples both in positive and negative modes of ESI (electrospray ionization) were all monitored. The relative standard deviations (RSDs) of peak intensity or retention time were calculated and were listed in Table 5. The validation results indicated the chromatographic and spectrometric system were well-suited for the following metabolomics analysis. 
Table 5. The RSDs (\%) of peak intensity and retention time in validation test.

\begin{tabular}{ccccccccccc}
\hline & \multicolumn{4}{c}{ Serum } & & \multicolumn{2}{c}{ Liver } \\
\cline { 2 - 9 } & \multicolumn{2}{c}{ Peak Intensity } & \multicolumn{2}{c}{ Retention Time } & \multicolumn{2}{c}{ Peak Intensity } & \multicolumn{2}{c}{ Retention Time } \\
\cline { 2 - 10 } & ESI+ & ESI- & ESI+ & ESI- & ESI+ & ESI- & ESI+ & ESI- \\
\hline $\begin{array}{c}\text { Stability } \\
\text { of LC-MS system }\end{array}$ & $1.56-5.57$ & $1.02-4.98$ & $0.23-2.35$ & $0.64-2.74$ & $1.97-7.14$ & $1.34-6.61$ & $0.63-3.22$ & $0.89-2.71$ \\
\hline Injection Precision & $0.92-3.09$ & $1.06-5.14$ & $0.66-2.48$ & $0.97-3.05$ & $1.36-6.47$ & $2.14-6.83$ & $0.74-3.53$ & $0.98-3.33$ \\
\hline $\begin{array}{c}\text { Reproducibility of sample } \\
\text { preparation }\end{array}$ & $2.12-6.69$ & $1.68-6.57$ & $1.02-4.39$ & $1.25-3.35$ & $2.77-5.61$ & $2.19-5.88$ & $1.30-2.94$ & $1.28-4.38$ \\
\hline $\begin{array}{c}\text { Post-preparation stability } \\
\text { of sample }\end{array}$ & $2.39-6.41$ & $2.01-5.27$ & $1.23-4.18$ & $1.36-3.99$ & $1.44-4.34$ & $1.67-5.25$ & $1.33-3.36$ & $1.41-3.79$ \\
\hline
\end{tabular}

The serum and liver metabolic characteristics of normal group, model group and compound $2 \mathbf{e}(100 \mathrm{mg} / \mathrm{kg})$ group in positive ESI (ESI+) and negative ESI (ESI-) modes were acquired. The representative BPI (base peak intensity) chromatograms are shown in Figure 5.
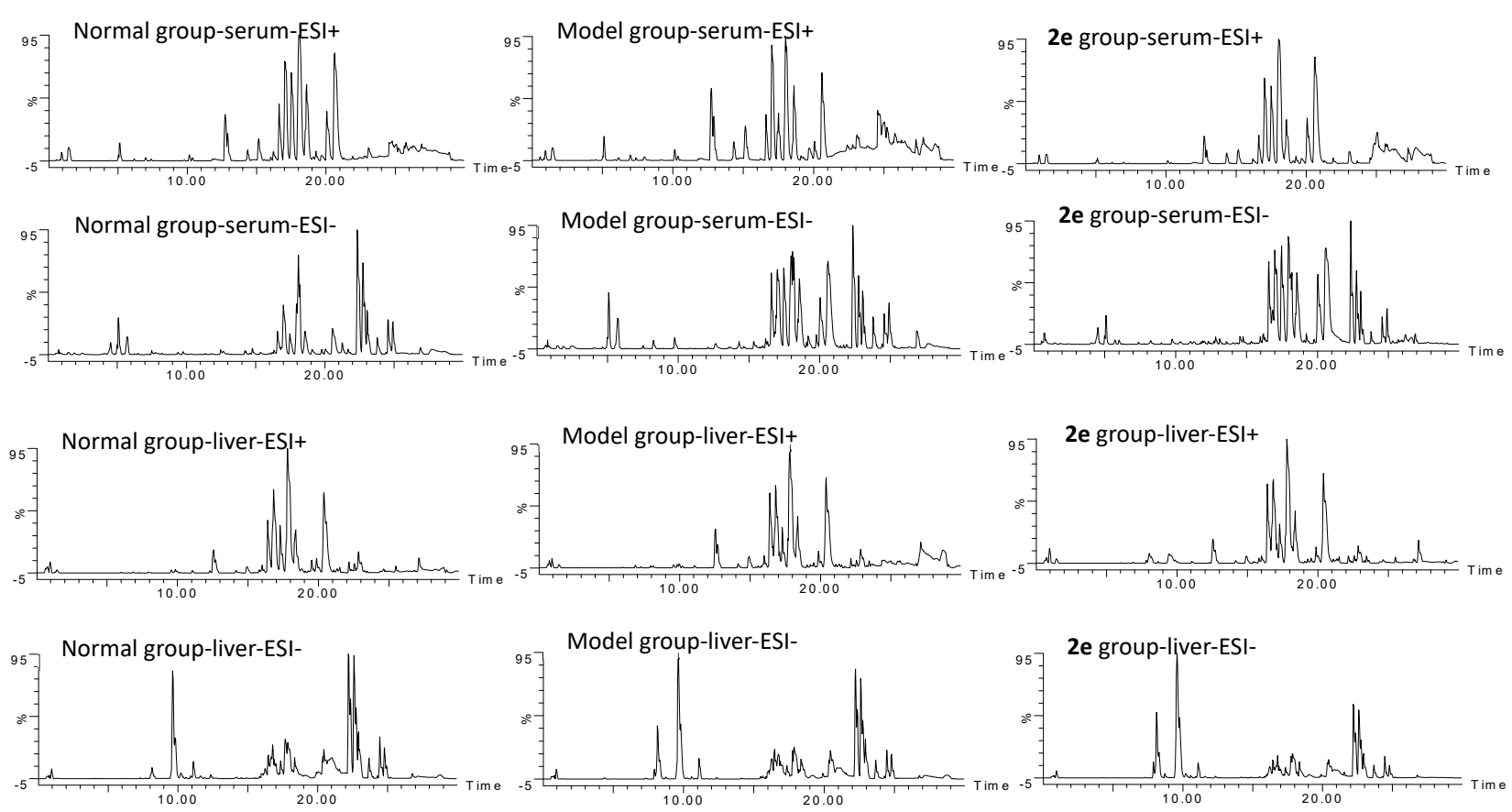

Figure 5. The representative base peak intensity (BPI) chromatograms in ESI+ and ESI- modes.

\subsubsection{Identification of the Differential Metabolites and Metabolic Pathways}

In order to confirm whether the endogenous metabolites were different in serum or in liver between normal, model and compound $\mathbf{2 e}$ groups, principal component analysis (PCA), an unsupervised pattern recognition approach, was firstly performed in both ESI+ and ESI- modes (Figure 6A-D). Both in serum and in liver PCA scores, each spot represented a sample; the tightly clustered QC spots indicated the satisfactory stability of system; three groups were separated indicating their being differential; compound 2e group was located between the normal group and the model group, indicating that compound $2 \mathrm{e}$ might regulate the metabolic disturbances in $\mathrm{H} 22$ tumor-bearing mice. 

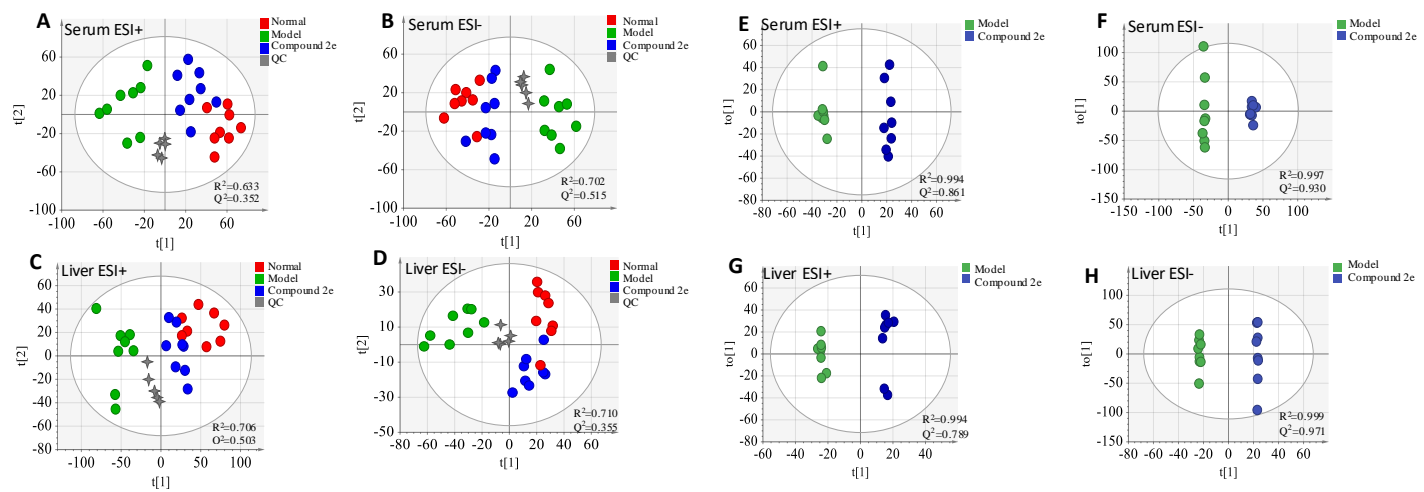

Figure 6. Principal component analysis (PCA) (A-D) and OPLS-DA (E-H) score plots of serum and liver metabolic profiling.

Aiming at obtaining the maximum separation between the model group and compound 2e group, orthogonal projections to latent structures discriminant analysis (OPLSDA), a supervised method of pattern recognition, was then established in both ESI+ and ESI- modes (Figure 6E-H). In the OPLS-DA score plots, each spot also represented a serum or a liver sample. Either in serum samples or in liver samples, the model group and compound 2e group were both separated with satisfactory $\mathrm{R}^{2}$ and $\mathrm{Q}^{2}$ parameters.

Permutation test was then performed to validate the prediction ability and the reliability of OPLS-DA. Figure 7A-D showed the test results. All $\mathrm{Q}^{2}$-values (blue spots) to the left were lower than the original points to the right, indicating that the OPLS-DA displayed good prediction ability and reliability.
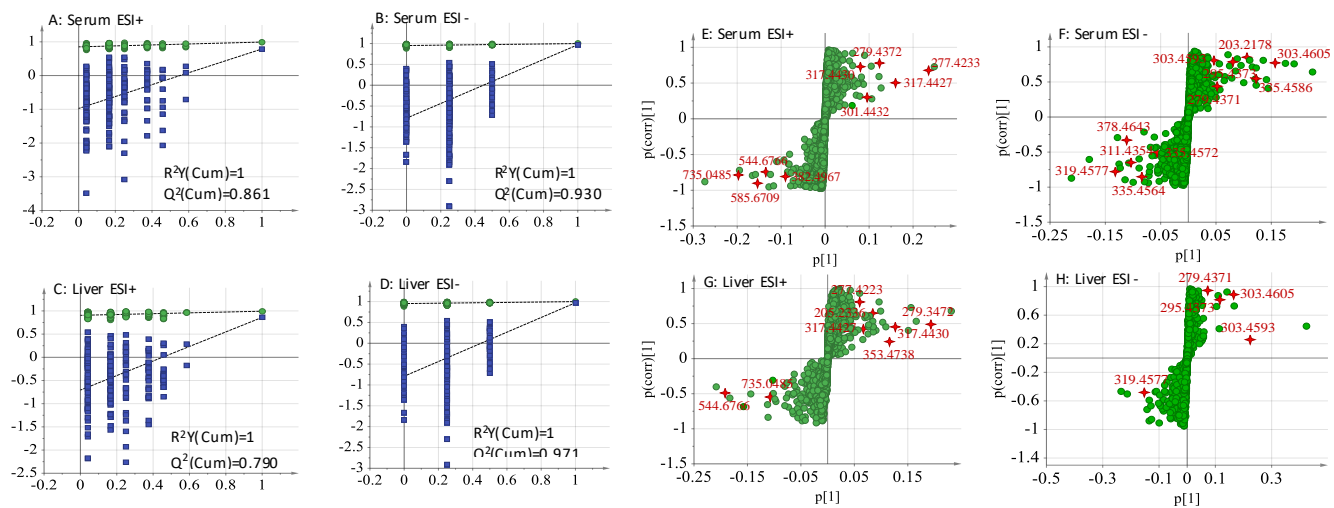

Figure 7. The permutation plots (A-D) and S-plots (E-H) of serum and the liver metabolic profiling.

To find the potential biomarkers that contributed to the differentiation between the model group and compound 2e group, S-plots (Figure 7E-H) under OPLS-DA were generated to visualize the variables. Each spot in S-plots represents an endogenous metabolite in the model group and compound $2 \mathbf{e}$ group. The farther away the spot in the S-plots from the origin, the more significantly the metabolite contribute to the clustering of two groups. The metabolites with VIP (variable importance in the projection) $>1.0$ and $p<0.05$ were considered as potential biomarkers. There were 21 robust endogenous metabolites were identified as the candidate biomarkers (listed in Table 6). These biomarkers were marked with measured mass in S-plots. And it was showed that these biomarkers were involved in eight metabolic pathways (Table 7). The relationship between the main metabolites \& its involved metabolisms and liver diseases is discussed as follows:

Arachidonic acid metabolism (AM): (1) Arachidonic acid (AA), recognized as the main factor mediating repeated liver injury and compensatory proliferation [62,63], could suppress the growth of hepatic cells and increase cellular transglutaminase 2 transamidase activity. The elevated serum levels of AA had been observed in HCC Patients. (2) 8,9- 
epoxyeicosatrienoic acid (8,9-EET), a kind of epoxyeicosatrienoic acids (EETs), was closely related to hepatic tumor [64]. (3) 15(S)-hydroperoxy eicosatetraenoic acid (15(S)-HPETE) decreased production of CD31 and VEGF in endothelial cells and had an anti-angiogenic effect in adipose tissue $[65,66]$. (4) Leukotriene B4 (LTB4) played a role in acute and chronic liver injury. It is important in mediating the inflammatory response, and it is involved in pathogenesis of several autoimmune, inflammatory diseases as well as in tumor proliferation [67]. (5) Prostaglandin I2 (PGI2), an important downstream from AA, is also a mediator of tumor progression [68]. Exogenous PGI2 could decrease tumor cell proliferation. In this experiment, the elevated levels (AA, 8, 9-EET, 5-HPETE, LTB4) and decreased levels (15(S)-HPETE, PGI2) in the model group indicated the imbalance of arachidonic acid metabolism. While the above levels could be re-regulated by compound $2 \mathbf{e}$ treatment.

Linoleic acid metabolism (LM): (1) Phosphatidylcholine (16:0/16:1) (PC(16:0/16:0)), a precursor of lipid inflammatory mediators, was specifically localized in colorectal cancer region [69,70]. (2) 12,13-epoxyoctadecenoic acid (12,13-EpOME), a metabolite of CYP monooxygenase, has proinflammatory effect. In this experiment, the elevated levels of PC (16:0/16:1) and 12, 13-EpOME observed in the model group, could be re-regulated by compound $2 \mathbf{e}$.

Sphingolipid metabolism (SM): Sphinganine 1-phosphate (Sa1-P) and sphingosine 1phosphate (So1-P) were the bioactive phospholipids involved in proliferation of HepG2 cells in vivo [71,72]. In the current study, Sa1-P and So1-P increased in the model group, could be re-regulated by compound $2 \mathbf{e}$.

Retinol metabolism (RM): In liver tumors, retinyl ester levels were significantly decreased [73]. Hydroxyretinoic acid and all-trans-5, 6-Epoxyretinoic acid could inhibit the growth of breast cancer cell and rat rhabdomyosarcoma cell [74]. All-trans-retinoic acid, the active metabolite of vitamin A, could affect liver cancer stem cells. All the above metabolites decreased in the model group and could be up-regulated following compound 2e treatment.

Porphyrin and chlorophyll metabolism (PCM): The level of bilirubin was significantly elevated in the H22 liver tumor model group [75]. In our study, bilirubin was also markedly decreased in the model group, and was re-regulated following compound 2e treatment.

Tryptophan metabolism (TryM): L-tryptophan, an essential amino acid for human, could prevent hepatic fibrosis progression [76]. It was shown that L-tryptophan decreased in the model group and could be re-regulated by compound $\mathbf{2 e}$.

Glycerophospholipid metabolism (GlyM): Altered glycerophospholipid metabolism (LysoPC a C18:1) has been reported in both blood and liver tissue samples from nonalcoholic fatty liver disease patients [77]. It had also been disturbed in the liver injury mouse model [78]. In our study, LysoPC (18:1(9Z)/0:0) increased in the model group and could be re-regulated by compound $\mathbf{2 e}$.

$\alpha$-Linolenic acid metabolism (ALAM): Alterations in phospholipid and fatty acid metabo lism may play key roles in hepatocarcinogenesis. It was reported that the tumor exhibited significantly lower level of $\alpha$-linolenic acid than peritumoral liver tissue [79]. Stearidonic acid inhibited intestinal tumor development and cancer cell proliferation, and could be potentially chemo-preventive [80]. All above metabolites, decreased in the model group and could be re-regulated by compound $2 \mathbf{e}$.

In addition, the predictive ROC curves, generated by using 21 candidate biomarkers, showed that the candidate biomarkers were potential diagnostic markers for liver tumor (Figure 8A) and were contributed to compound 2e treatment (Figure 8B). The area under curve (AUC) values and $p$-values of the biomarkers in ROC curves were listed in Table 8. 
Table 6. Distinct metabolites identified in serum and liver samples.

\begin{tabular}{|c|c|c|c|c|c|c|c|c|c|c|c|}
\hline No. & $\mathrm{tR} / \mathrm{min}$ & $\begin{array}{l}\text { Measured } \\
\text { Mass } \\
\text { (Da) }\end{array}$ & VIPvalue & Formula & $\begin{array}{c}\text { Mass Error } \\
\quad(\mathrm{ppm})\end{array}$ & Adducts & Biomarkers & $\begin{array}{c}\text { HMDB } \\
\text { ID }\end{array}$ & Pathway & Content Level & Source \\
\hline \multirow{2}{*}{$1 *$} & 1.51 & 203.2178 & 5.25 & \multirow{2}{*}{$\mathrm{C}_{11} \mathrm{H}_{12} \mathrm{~N}_{2} \mathrm{O}_{2}$} & 3.13 & $\mathrm{M}-\mathrm{H}$ & \multirow{2}{*}{ L-Tryptophan } & \multirow{2}{*}{0000929} & \multirow{2}{*}{$\operatorname{TrpM}$} & \multirow{2}{*}{$\mathrm{C}_{\mathrm{M}}<\mathrm{C}_{2 \mathrm{e}}<\mathrm{C}_{\mathrm{N}}$} & Serum \\
\hline & 1.49 & 205.2336 & 2.84 & & 2.21 & $\mathrm{M}+\mathrm{H}$ & & & & & Liver \\
\hline \multirow{2}{*}{$2^{a}$} & \multirow{2}{*}{10.1} & \multirow{2}{*}{317.4430} & 4.34 & \multirow{2}{*}{$\mathrm{C}_{20} \mathrm{H}_{28} \mathrm{O}_{3}$} & \multirow{2}{*}{1.45} & $\mathrm{M}+\mathrm{H}$ & \multirow{2}{*}{ 4-Hydroxyretinoic acid } & \multirow{2}{*}{0006254} & \multirow{2}{*}{$\mathrm{RM}$} & \multirow{2}{*}{$\mathrm{C}_{\mathrm{M}}<\mathrm{C}_{2 \mathrm{e}} \approx \mathrm{C}_{\mathrm{N}}$} & Serum \\
\hline & & & 4.66 & & & $\mathrm{M}+\mathrm{H}$ & & & & & Liver \\
\hline $4^{a}$ & 14.06 & 335.4564 & 4.17 & $\mathrm{C}_{20} \mathrm{H}_{32} \mathrm{O}_{4}$ & -3.87 & $\mathrm{M}-\mathrm{H}$ & Leukotriene B4 & 0001085 & $\mathrm{AM}$ & $\mathrm{C}_{\mathrm{M}}>\mathrm{C}_{2 \mathrm{e}} \approx \mathrm{C}_{\mathrm{N}}$ & Serum \\
\hline $5^{a}$ & 14.58 & 335.4586 & 7.36 & $\mathrm{C}_{20} \mathrm{H}_{32} \mathrm{O}_{4}$ & 2.62 & $\mathrm{M}-\mathrm{H}$ & 15(S)-HPETE & 0004244 & $\mathrm{AM}$ & $\mathrm{C}_{\mathrm{M}}<\mathrm{C}_{\mathrm{N}}<\mathrm{C}_{2 \mathrm{e}}$ & Serum \\
\hline \multirow{2}{*}{$6^{a}$} & \multirow{2}{*}{14.59} & \multirow{2}{*}{295.4373} & 4.04 & \multirow{2}{*}{$\mathrm{C}_{18} \mathrm{H}_{32} \mathrm{O}_{3}$} & \multirow{2}{*}{1.19} & $\mathrm{M}-\mathrm{H}$ & \multirow{2}{*}{ 12,13-ЕpOME } & \multirow{2}{*}{0004702} & \multirow{2}{*}{ LM } & \multirow{2}{*}{$\mathrm{C}_{\mathrm{M}}>\mathrm{C}_{2 \mathrm{e}} \approx \mathrm{C}_{\mathrm{N}}$} & Serum \\
\hline & & & 3.57 & & & $\mathrm{M}-\mathrm{H}$ & & & & & Liver \\
\hline $7^{\mathrm{a}}$ & 14.61 & 301.4432 & 6.29 & $\mathrm{C}_{20} \mathrm{H}_{28} \mathrm{O}_{2}$ & 0.37 & $\mathrm{M}+\mathrm{H}$ & all-trans-Retinoic acid & 0001852 & $\mathrm{RM}$ & $\mathrm{C}_{\mathrm{M}}<\mathrm{C}_{\mathrm{N}}<\mathrm{C}_{2 \mathrm{e}}$ & Serum \\
\hline $8^{a}$ & 14.64 & 277.4223 & 12.73 & $\mathrm{C}_{18} \mathrm{H}_{28} \mathrm{O}_{2}$ & 2.11 & $\mathrm{M}+\mathrm{H}$ & Stearidonic acid & 0006547 & ALAM & $\mathrm{C}_{M}<\mathrm{C}_{2 \mathrm{e}} \approx \mathrm{C}_{\mathrm{N}}$ & Serum \\
\hline $9^{a}$ & 15.38 & 378.4643 & 8.27 & $\mathrm{C}_{18} \mathrm{H}_{38} \mathrm{NO}_{5} \mathrm{P}$ & 1.21 & $\mathrm{M}-\mathrm{H}$ & Sphingosine 1-phosphate & 0000277 & SM & $\mathrm{C}_{\mathrm{M}}>\mathrm{C}_{\mathrm{N}}>\mathrm{C}_{2 \mathrm{e}}$ & Serum \\
\hline $10^{\mathrm{a}}$ & 16.02 & 382.4967 & 5.18 & $\mathrm{C}_{18} \mathrm{H}_{40} \mathrm{NO}_{5} \mathrm{P}$ & 2.87 & $\mathrm{M}+\mathrm{H}$ & Sphinganine 1-phosphate & 0001383 & $\mathrm{SM}$ & $\mathrm{C}_{\mathrm{M}}>\mathrm{C}_{2 \mathrm{e}} \approx \mathrm{C}_{\mathrm{N}}$ & Serum \\
\hline $11^{\mathrm{a}}$ & 16.28 & 335.4572 & 3.18 & $\mathrm{C}_{20} \mathrm{H}_{32} \mathrm{O}_{4}$ & -1.4 & $\mathrm{M}-\mathrm{H}$ & $\begin{array}{c}5(S)- \\
\text { Hydroperoxyeicosatetraenoic } \\
\text { acid }\end{array}$ & 0001193 & $\mathrm{AM}$ & $\mathrm{C}_{\mathrm{M}}>\mathrm{C}_{2 \mathrm{e}} \approx \mathrm{C}_{\mathrm{N}}$ & Serum \\
\hline $12^{\mathrm{a}}$ & 16.93 & 311.4354 & 5.29 & $\mathrm{C}_{18} \mathrm{H}_{32} \mathrm{O}_{4}$ & -2.97 & $\mathrm{M}-\mathrm{H}$ & $\begin{array}{l}\text { 13-L-Hydroperoxylinoleic } \\
\text { acid }\end{array}$ & 0003871 & LM & $\mathrm{C}_{\mathrm{M}}>\mathrm{C}_{2 \mathrm{e}} \approx \mathrm{C}_{\mathrm{N}}$ & Serum \\
\hline $13^{\mathrm{a}}$ & 17.74 & 317.4427 & 11.07 & $\mathrm{C}_{20} \mathrm{H}_{28} \mathrm{O}_{3}$ & 0.53 & $\mathrm{M}+\mathrm{H}$ & all-trans-5,6-Epoxyretinoic & 0012451 & RM & $\mathrm{C}_{\mathrm{M}}<\mathrm{C}_{2 \mathrm{e}} \approx \mathrm{C}_{\mathrm{N}}$ & Serum \\
\hline & 17.49 & & 2.14 & & & $\mathrm{M}+\mathrm{H}$ & & & & & Liver \\
\hline $14^{\mathrm{a}}$ & 1813 & 3194577 & 7.58 & $\mathrm{C}_{20} \mathrm{H}_{32} \mathrm{O}_{3}$ & -178 & $\mathrm{M}-\mathrm{H}$ & 8,9-Epoxyeicosatrienoic & 0002232 & $\mathrm{AM}$ & $\mathrm{C}_{\mathrm{M}}>\mathrm{C}_{2 \mathrm{e}}>\mathrm{C}_{\mathrm{N}}$ & Serum \\
\hline & & & 2.19 & & & $\mathrm{M}-\mathrm{H}$ & & & & & Liver \\
\hline $15 \mathrm{a}$ & 1824 & 5446766 & 8.01 & $\mathrm{C}^{2} \mathrm{H}_{-2} \mathrm{NO}^{-\mathrm{P}}$ & 2.43 & $\mathrm{M}+\mathrm{Na}$ & IvsoPC $(18 \cdot 1(97) / 0 \cdot 0)$ & 0002815 & GlvM & $\mathrm{C}_{\mathrm{M}}>\mathrm{C}_{\mathrm{N}}>\mathrm{C}_{2}$ & Serum \\
\hline & 10.24 & & 10.90 & & -1.32 & $\mathrm{M}+\mathrm{H}$ & & & & & Liver \\
\hline
\end{tabular}


Table 6. Cont.

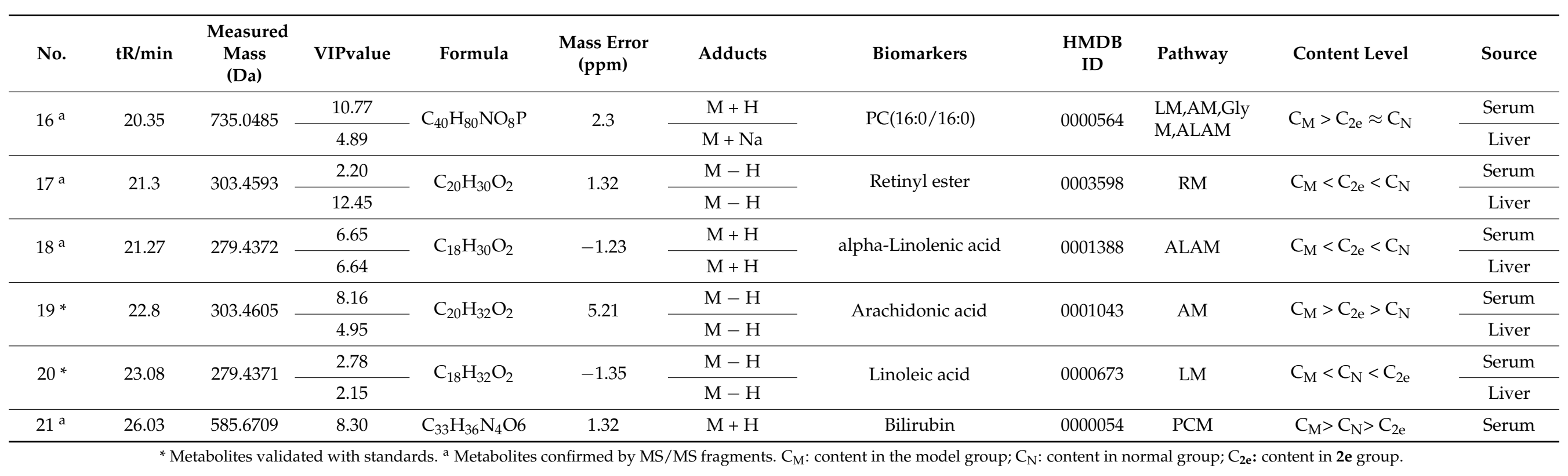


Table 7. The results from metabolic pathways of differential metabolites.

\begin{tabular}{|c|c|c|c|c|c|c|}
\hline Pathway Name & Match Status & $p$-Value & $-\log (p)$ & Holm $p$ & FDR & Impact \\
\hline Arachidonic acid metabolism (AM) & $24 / 36$ & $<0.0001$ & 9.5736 & $<0.0001$ & $<0.0001$ & 0.7712 \\
\hline Linoleic acid metabolism (LM) & $5 / 5$ & $<0.0001$ & 3.6273 & 0.0191 & 0.0066 & 1.0000 \\
\hline Retinol metabolism (RM) & $7 / 16$ & 0.0192 & 1.7123 & 1.0000 & 0.4073 & 0.6347 \\
\hline Sphingolipid metabolism (SM) & $6 / 21$ & 0.1913 & 0.7183 & 1.0000 & 1.0000 & 0.3185 \\
\hline Alpha-linolenic acid metabolism (ALAM) & $3 / 13$ & 0.4586 & 0.3386 & 1.0000 & 1.0000 & 0.3333 \\
\hline Glycerophospholipid metabolism (GlyM) & $5 / 36$ & 0.8408 & 0.075 & 1.0000 & 1.0000 & 0.4032 \\
\hline Porphyrin and chlorophyll metabolis (PCM) & $4 / 30$ & 0.8486 & 0.071 & 1.0000 & 1.0000 & 0.2986 \\
\hline Tryptophan metabolism (TryM) & $1 / 41$ & 0.9998 & $<0.0001$ & 1.0000 & 1.0000 & 0.1430 \\
\hline
\end{tabular}
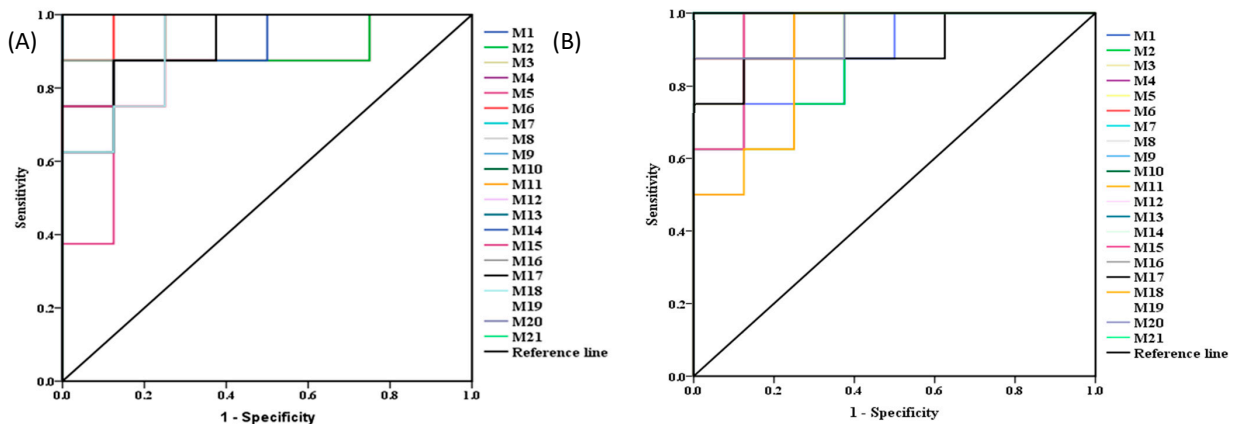

Figure 8. The predictive receiver operating characteristic (ROC) curves generated using 21 biomarkers contributing to (A) liver-tumor progress between model group and normal group, (B) compound $2 \mathbf{e}$ treatment between model group and compound $2 \mathbf{e}$ group.

Table 8. The area under curve (AUC) values and $p$-values of the biomarkers in two predictive ROC curves.

\begin{tabular}{|c|c|c|c|c|c|c|c|c|c|}
\hline \multirow{2}{*}{ No. } & \multicolumn{2}{|c|}{$\mathbf{M}$ and $\mathbf{N}$} & \multicolumn{2}{|c|}{$\mathrm{M}$ and Compound $2 \mathrm{e}$} & \multirow{2}{*}{ No. } & \multicolumn{2}{|c|}{$\mathbf{M}$ and $\mathbf{N}$} & \multicolumn{2}{|c|}{$\mathbf{M}$ and Compound $2 \mathrm{e}$} \\
\hline & AUC & $p$-Value & AUC & $p$-Value & & AUC & $p$-Value & AUC & $p$-Value \\
\hline 1 & 1 & 0.001 & 0.953 & 0.001 & 12 & 0.984 & 0.002 & 1.000 & 0.002 \\
\hline 2 & 0.906 & 0.020 & 0.875 & 0.015 & 13 & 1.000 & 0.001 & 1.000 & 0.001 \\
\hline 3 & 0.953 & 0.001 & 0.984 & 0.001 & 14 & 0.922 & 0.001 & 0.891 & 0.004 \\
\hline 4 & 0.938 & 0.001 & 0.969 & 0.001 & 15 & 0.938 & 0.003 & 0.953 & 0.001 \\
\hline 5 & 0.891 & 0.010 & 0.938 & 0.001 & 16 & 0.953 & 0.003 & 0.969 & 0.001 \\
\hline 6 & 1.000 & 0.001 & 1.000 & 0.001 & 17 & 0.922 & 0.002 & 0.906 & 0.005 \\
\hline 7 & 1.000 & 0.001 & 1.000 & 0.001 & 18 & 0.922 & 0.001 & 0.891 & 0.006 \\
\hline 8 & 0.969 & 0.001 & 0.938 & 0.002 & 19 & 0.953 & 0.001 & 0.891 & 0.019 \\
\hline 9 & 0.938 & 0.002 & 1.000 & 0.001 & 20 & 0.906 & 0.014 & 0.953 & 0.005 \\
\hline 10 & 0.953 & 0.003 & 1.000 & 0.002 & 21 & 0.891 & 0.008 & 1.000 & 0.021 \\
\hline 11 & 0.953 & 0.002 & 0.969 & 0.001 & - & - & - & - & - \\
\hline
\end{tabular}

M: model group; N: normal group; 2e: compound 2e group.

In order to characterize and visualize the biomarkers' relative abundance in three groups, the heatmap (Figure 9A) was then generated with green color representing low abundance and red color representing high abundance. Moreover, the established metabolic network of the biomarkers was shown in Figure 9B. 
(A)

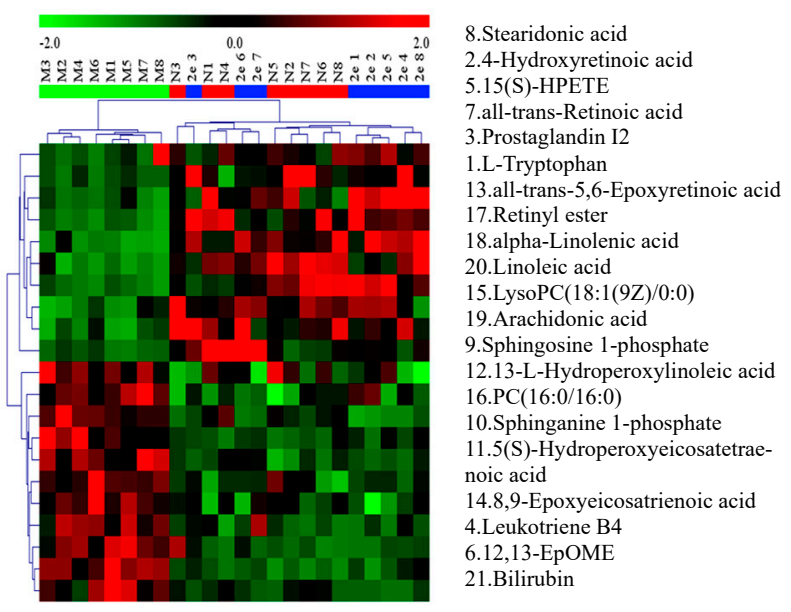

(B)

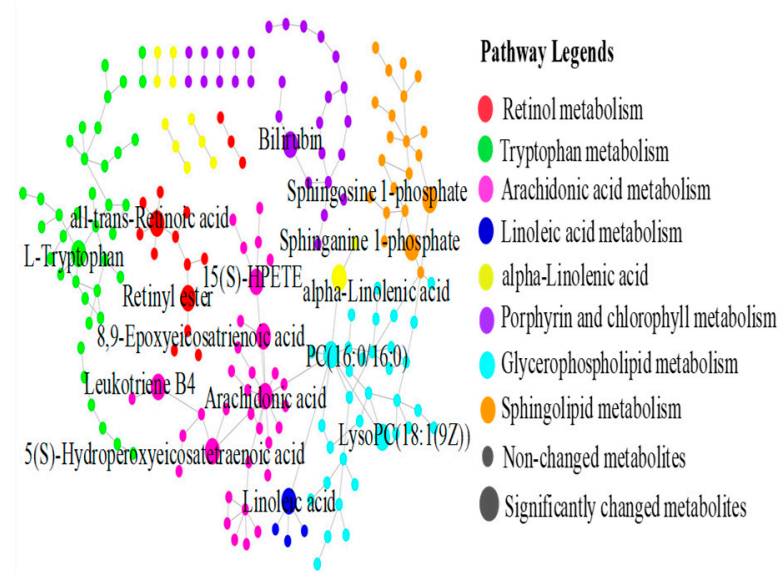

Figure 9. The heatmap (A) and the metabolic pathways (B) of all potential biomarkers.

\section{Materials and Method}

\subsection{Chemistry}

The ${ }^{1} \mathrm{H}-\mathrm{NMR}$ and ${ }^{13} \mathrm{C}-\mathrm{NMR}$ spectra using TMS as internal standard was assayed in $\mathrm{CDCl}_{3}$ or Pyridin- $\mathrm{d}_{5}$ on Bruker AV-600 spectrometer (Bruker Co., Karlsruhe, Germany). Chemical shifts were expressed in $\delta$ values (ppm). High-resolution electrospray ionization mass spectrometry (HR-ESI-MS) was performed on Waters Xevo G2-XS QTOF mass spectrometer (Waters Co., Milford, MA, USA). Chemical reagents and solvents were purchased from Saen Chemical Technology Co., Ltd. (Shanghai, China).

\subsubsection{The Synthesis of Compounds 1a-1f and 3a-3f}

At room temperature, $\mathrm{EDC}(3.15 \mathrm{mmol})$ and DMAP $(1.05 \mathrm{mmol})$ in dry $\mathrm{CH}_{2} \mathrm{Cl}_{2}(20 \mathrm{~mL})$ were added to $\mathrm{N}$-Boc protected amino acids $(4.20 \mathrm{mmol})$ solution in a triangle flask with a magnetic stirrer. Pyxinol $(2.10 \mathrm{mmol})$ was added $30 \mathrm{~min}$ later. The reaction mixtures were shaken for $12 \mathrm{~h}$ and progress was monitored by TLC ( $n$-hexane/ethyl acetate 3:1). Then the organic solution was washed with saturated aqueous $\mathrm{NaHCO}_{3}$ solution $(3 \times 10 \mathrm{~mL})$, water $(3 \times 10 \mathrm{~mL})$ and brine $(3 \times 10 \mathrm{~mL})$, dried $\left(\mathrm{MgSO}_{4}\right)$, filtered and concentrated under reduced pressure to give the crude product. The crude products were chromatographed using silica gel and eluted with $n$-hexane and ethyl acetate (5:1) to obtain the pure products 1a-1f used as substrates for the Boc deprotection reaction. The ocotillol N-Boc protected amino acids derivatives $\mathbf{3 a}-\mathbf{3} \mathbf{f}$ using the same procedure described above for compounds 1a-1f, except all reactants were dissolved in THF.

(20S, 24R)-Epoxy-3ß-O-(Boc-L-alanyl)-dammarane-12 $\beta$, 25-diol (1a)

Light yellow powder (yield 96.8\%), ${ }^{1} \mathrm{H}-\mathrm{NMR}\left(\mathrm{CDCl}_{3}, 600 \mathrm{MHz}\right) \delta 5.55(\mathrm{~s}, 1 \mathrm{H}), 5.04$ (s, $1 \mathrm{H}), 4.49(\mathrm{dd}, J=9.3,7.1 \mathrm{~Hz}, 1 \mathrm{H}), 4.30-4.26(\mathrm{~m}, 1 \mathrm{H}), 3.84-3.81(\mathrm{~m}, 1 \mathrm{H}), 3.51-3.46(\mathrm{~m}$, $1 \mathrm{H}), 2.19-2.14(\mathrm{~m}, 1 \mathrm{H}), 2.06-1.92(\mathrm{~m}, 2 \mathrm{H}), 1.89-1.81(\mathrm{~m}, 3 \mathrm{H}), 1.72-1.62(\mathrm{~m}, 6 \mathrm{H}), 1.57-1.50(\mathrm{~m}$, $4 \mathrm{H}), 1.42\left(\mathrm{~s}, 12 \mathrm{H}, 4 \times-\mathrm{CH}_{3}\right), 1.37(\mathrm{~d}, J=7.2 \mathrm{~Hz}, 3 \mathrm{H}), 1.29-1.27(\mathrm{~m}, 2 \mathrm{H}), 1.25\left(\mathrm{~s},-\mathrm{CH}_{3}\right), 1.24$ $\left(\mathrm{s},-\mathrm{CH}_{3}\right), 1.12-1.09(\mathrm{~m}, 2 \mathrm{H}), 1.07\left(\mathrm{~s},-\mathrm{CH}_{3}\right), 0.96\left(\mathrm{~s},-\mathrm{CH}_{3}\right), 0.94-0.92(\mathrm{~m}, 1 \mathrm{H}), 0.87(\mathrm{~s},-$ $\left.\mathrm{CH}_{3}\right), 0.86\left(\mathrm{~s},-\mathrm{CH}_{3}\right), 0.84\left(\mathrm{~s},-\mathrm{CH}_{3}\right), 0.81(\mathrm{~s},-\mathrm{CH} 3) .{ }^{13} \mathrm{C}-\mathrm{NMR}\left(\mathrm{CDCl}_{3}, 150 \mathrm{MHz}\right) \delta 173.24$, $155.19,86.73,85.65,82.07,79.88,71.15,70.31,56.26,52.23,50.64,49.77,49.62,48.18,39.99$, $38.80,38.26,37.29,34.97,32.84,31.57,31.43,30.79,28.81,28.58(\times 3 C), 28.16,27.82,26.37$, $25.22,23.89,19.41,19.19,18.38,16.67,16.59,15.62 . H R-M S(E S I, m / z)[M+H]^{+}$calcd. for $\mathrm{C}_{38} \mathrm{H}_{65} \mathrm{NO}_{7}, 648.4839$, found: 648.4834 .

(20S, 24R)-Epoxy-3 $\beta$-O-(Boc-L-methinyl)-dammarane-12 $\beta$, 25-diol (1b)

Yellow powder (yield 86.2\%), ${ }^{1} \mathrm{H}-\mathrm{NMR}\left(\mathrm{CDCl}_{3}, 600 \mathrm{MHz}\right) \delta 5.07(\mathrm{~s}, 1 \mathrm{H}), 4.51-4.48$ $(\mathrm{m}, 1 \mathrm{H}), 4.39-4.37(\mathrm{~m}, 1 \mathrm{H}), 3.84-3.81(\mathrm{~m}, 1 \mathrm{H}), 3.49(\mathrm{td}, J=10.5,4.5 \mathrm{~Hz}, 1 \mathrm{H}), 2.54-2.50$ $(\mathrm{m}, 2 \mathrm{H}), 2.19-2.15(\mathrm{~m}, 2 \mathrm{H}), 2.07\left(\mathrm{~s},-\mathrm{SCH}_{3}\right), 2.02-1.81(\mathrm{~m}, 7 \mathrm{H}), 1.71-1.50(\mathrm{~m}, 10 \mathrm{H}), 1.42$ 
$\left(\mathrm{s}, 3 \times-\mathrm{CH}_{3}\right), 1.29-1.27(\mathrm{~m}, 2 \mathrm{H}), 1.25\left(\mathrm{~s},-\mathrm{CH}_{3}\right), 1.24\left(\mathrm{~s},-\mathrm{CH}_{3}\right), 1.12-1.09(\mathrm{~m}, 2 \mathrm{H}), 1.07$ $\left(\mathrm{s},-\mathrm{CH}_{3}\right), 1.05-1.00(\mathrm{~m}, 1 \mathrm{H}), 0.96\left(\mathrm{~s},-\mathrm{CH}_{3}\right), 0.87\left(\mathrm{~s},-\mathrm{CH}_{3}\right), 0.86\left(\mathrm{~s},-\mathrm{CH}_{3}\right), 0.84\left(\mathrm{~s},-\mathrm{CH}_{3}\right), 0.82$ $\left(\mathrm{s},-\mathrm{CH}_{3}\right) .{ }^{13} \mathrm{C}-\mathrm{NMR}\left(\mathrm{CDCl}_{3}, 150 \mathrm{MHz}\right) \delta 172.18,155.54,86.72,85.64,82.57,80.11,71.13$, $70.31,56.27,53.46,52.22,50.63,49.61,48.18,39.98,38.78,38.18,37.28,34.96,32.83,32.74$, $31.56,31.42,30.23,28.80,28.55$ (×3C), 28.32, 28.13, 27.81, 26.36, 25.21, 23.89, $18.36(\times 2 \mathrm{C})$, $16.75,16.57,15.69,15.61$. HR-MS (ESI, m/z) $[\mathrm{M}+\mathrm{H}]^{+}$calcd. for $\mathrm{C}_{40} \mathrm{H}_{69} \mathrm{NO}_{7} \mathrm{~S}, 708.4873$, found: 708.4876 .

(20S, 24R)-Epoxy-3 $\beta$-O-(Boc-L-glycyl)-dammarane-12 $\beta, 25$-diol (1c)

White powder (yield 83.7\%), ${ }^{1} \mathrm{H}-\mathrm{NMR}\left(\mathrm{CDCl}_{3}, 600 \mathrm{MHz}\right) \delta 4.97(\mathrm{~s}, 1 \mathrm{H}), 4.53-4.50$ $(\mathrm{m}, 1 \mathrm{H}), 3.87(\mathrm{~d}, J=5.1 \mathrm{~Hz}, 2 \mathrm{H}), 3.84-3.81(\mathrm{~m}, 1 \mathrm{H}), 3.51-3.46(\mathrm{td}, J=10.5,4.6 \mathrm{~Hz}, 1 \mathrm{H})$, 2.19-2.14 (m, 1H), 2.05-1.81 (m, 6H), 1.72-1.46 (m, 9H), $1.43\left(\mathrm{~s}, 3 \times-\mathrm{CH}_{3}\right), 1.41-1.37(\mathrm{~m}, 1 \mathrm{H})$, 1.30-1.27 (m, 2H), $1.25\left(\mathrm{~s},-\mathrm{CH}_{3}\right), 1.24\left(\mathrm{~s},-\mathrm{CH}_{3}\right), 1.12-1.09(\mathrm{~m}, 2 \mathrm{H}), 1.07\left(\mathrm{~s},-\mathrm{CH}_{3}\right), 1.05-1.00$ $(\mathrm{m}, 1 \mathrm{H}), 0.96\left(\mathrm{~s},-\mathrm{CH}_{3}\right), 0.87\left(\mathrm{~s},-\mathrm{CH}_{3}\right), 0.85\left(\mathrm{~s},-\mathrm{CH}_{3}\right), 0.82\left(\mathrm{~s}, 2 \times-\mathrm{CH}_{3}\right) .{ }^{13} \mathrm{C}-\mathrm{NMR}\left(\mathrm{CDCl}_{3}\right.$, $150 \mathrm{MHz}) \delta 170.33,155.84,86.73,85.65,82.36,80.08,71.15,70.32,56.27,52.23,50.64,49.61$, $48.19,42.87,39.99,38.82,38.20,37.28,34.97,32.83,31.56,31.43,28.81,28.55(\times 3 C), 28.21$, $28.14,27.82,26.36,25.22,23.89,18.37(\times 2 \mathrm{C}), 16.60(\times 2 \mathrm{C}), 15.62$. HR-MS $(\mathrm{ESI}, \mathrm{m} / \mathrm{z})[\mathrm{M}+$ $\mathrm{H}]^{+}$calcd. for $\mathrm{C}_{37} \mathrm{H}_{63} \mathrm{NO}_{7}, 634.4683$, found: 634.4687 .

(20S, 24R)-Epoxy-3 $\beta$-O-(Boc-L-leucyl)-dammarane-12 $\beta, 25-$ diol (1d)

Light yellow powder (yield 79.1\%), ${ }^{1} \mathrm{H}-\mathrm{NMR}\left(\mathrm{CDCl}_{3}, 600 \mathrm{MHz}\right) \delta 4.83(\mathrm{~s}, 1 \mathrm{H})$, 4.49-4.46 (m, 1H), 4.28-4.23 (m, 1H), 3.84-3.81 (m, 1H), 3.49 (td, $J=10.5,4.5 \mathrm{~Hz}, 1 \mathrm{H})$, 2.19-2.14 (m, 1H), 2.02-1.98 (m, 2H), 1.87-1.84 (m, 3H), 1.74-1.43 (m, 14H), $1.41\left(\mathrm{~s},-\mathrm{CH}_{3}\right)$, $1.30-1.27(\mathrm{~m}, 2 \mathrm{H}), 1.25\left(\mathrm{~s},-\mathrm{CH}_{3}\right), 1.24\left(\mathrm{~s},-\mathrm{CH}_{3}\right), 1.12-1.09(\mathrm{~m}, 2 \mathrm{H}), 1.07\left(\mathrm{~s},-\mathrm{CH}_{3}\right), 1.05-1.00$ $(\mathrm{m}, 1 \mathrm{H}), 0.96\left(\mathrm{~s},-\mathrm{CH}_{3}\right), 0.93\left(\mathrm{~d}, J=1.6 \mathrm{~Hz}, 2 \times-\mathrm{CH}_{3}\right), 0.87\left(\mathrm{~s},-\mathrm{CH}_{3}\right), 0.86\left(\mathrm{~s},-\mathrm{CH}_{3}\right), 0.84$ $\left(\mathrm{s},-\mathrm{CH}_{3}\right), 0.82\left(\mathrm{~s},-\mathrm{CH}_{3}\right) .{ }^{13} \mathrm{C}-\mathrm{NMR}\left(\mathrm{CDCl}_{3}, 150 \mathrm{MHz}\right) \delta 73.33,155.58,86.73,85.65,82.02$, 79.86, 71.16, 70.31, 56.30, 52.77, 52.23, 50.64, 49.62, 48.18, 42.30, 39.99, 38.80, 38.18, 37.28, $34.98,32.84,31.56,31.42,29.92,28.81,28.57$ (×3C), 28.25, 28.13, 27.82, 26.36, 25.22, 25.07, $23.88,23.17,22.13,18.38,16.71,16.57,15.62$. HR-MS (ESI, $\mathrm{m} / \mathrm{z})[\mathrm{M}+\mathrm{H}]^{+}$calcd. for $\mathrm{C}_{41} \mathrm{H}_{71} \mathrm{NO}_{7}, 690.5309$, found: 690.5314 .

(20S, 24R)-Epoxy-3 $\beta$-O-(Boc-L-prolyl)-dammarane-12 $\beta$, 25-diol (1e)

Yellow powder (yield 86.2\%), ${ }^{1} \mathrm{H}-\mathrm{NMR}\left(\mathrm{CDCl}_{3}, 600 \mathrm{MHz}\right) \delta 4.53-4.49(\mathrm{~m}, 1 \mathrm{H}), 4.35-$ $4.33(\mathrm{~m}, 1 \mathrm{H}), 4.27-4.25(\mathrm{~m}, 1 \mathrm{H}), 3.88-3.85(\mathrm{~m}, 1 \mathrm{H}), 3.56-3.48(\mathrm{~m}, 2 \mathrm{H}), 2.27-2.16(\mathrm{~m}, 2 \mathrm{H})$, 2.08-1.86 (m, 10H), 1.71-1.64 (m, 6H), 1.61-1.55 (m,3H), $1.47\left(\mathrm{~s},-\mathrm{CH}_{3}\right), 1.44\left(\mathrm{~s}, 3 \times-\mathrm{CH}_{3}\right)$, $1.33-1.30(\mathrm{~m}, 2 \mathrm{H}), 1.30\left(\mathrm{~s},-\mathrm{CH}_{3}\right), 1.29\left(\mathrm{~s},-\mathrm{CH}_{3}\right), 1.16-1.13(\mathrm{~m}, 1 \mathrm{H}), 1.12\left(\mathrm{~s},-\mathrm{CH}_{3}\right), 1.10-1.04$ $(\mathrm{m}, 1 \mathrm{H}), 1.00\left(\mathrm{~s},-\mathrm{CH}_{3}\right), 0.98-0.93(\mathrm{~m}, 1 \mathrm{H}), 0.92\left(\mathrm{~s},-\mathrm{CH}_{3}\right), 0.90\left(\mathrm{~s},-\mathrm{CH}_{3}\right), 0.87\left(\mathrm{~s},-\mathrm{CH}_{3}\right)$. ${ }^{13} \mathrm{C}-\mathrm{NMR}\left(\mathrm{CDCl}_{3}, 150 \mathrm{MHz}\right) \delta 172.98,154.09,86.73,85.65,81.41,71.15,70.30,59.66,56.28$, $53.84,52.23,50.63,49.63,48.19,46.65,46.47,39.99,38.79,38.22,37.28,34.97,32.84,31.56$, $31.44,30.40,28.81,28.72,28.63,28.14,27.84,26.37,25.23,24.51,23.96,23.69,18.87,18.38$, 17.62, 16.59, 15.62. HR-MS (ESI, $\mathrm{m} / \mathrm{z}$ ) $[\mathrm{M}+\mathrm{H}]^{+}$calcd. for $\mathrm{C}_{40} \mathrm{H}_{67} \mathrm{NO}_{7}, 674.4996$, found: 674.5001.

(20S, 24R)-Epoxy-3 $\beta$-O-(Boc-L-valyl)-dammarane-12 $\beta, 25-$ diol (1f)

Light yellow powder (yield 78.6\%), ${ }^{1} \mathrm{H}-\mathrm{NMR}\left(\mathrm{CDCl}_{3}, 600 \mathrm{MHz}\right) \delta 4.95(\mathrm{~s}, 1 \mathrm{H}), 4.50$ $4.47(\mathrm{~m}, 1 \mathrm{H}), 4.20-4.18(\mathrm{~m}, 1 \mathrm{H}), 3.84-3.81(\mathrm{~m}, 1 \mathrm{H}), 3.51-3.46(\mathrm{td}, J=5,4.6 \mathrm{~Hz}, 1 \mathrm{H}), 2.19-2.14$ (m, 2H), 2.05-1.81 (m, 6H), 1.70-1.46 (m, 9H), $1.42\left(\mathrm{~s}, 4 \times-\mathrm{CH}_{3}\right), 1.32-1.27(\mathrm{~m}, 2 \mathrm{H}), 1.09$ $(\mathrm{m}, 2 \mathrm{H}), 1.25\left(\mathrm{~s},-\mathrm{CH}_{3}\right), 1.24\left(\mathrm{~s},-\mathrm{CH}_{3}\right), 1.12-1.09(\mathrm{~m}, 1 \mathrm{H}), 1.07\left(\mathrm{~s},-\mathrm{CH}_{3}\right), 1.04-1.01(\mathrm{~m}, 1 \mathrm{H})$, $0.97\left(\mathrm{~s},-\mathrm{CH}_{3}\right), 0.96\left(\mathrm{~s},-\mathrm{CH}_{3}\right), 0.95\left(\mathrm{~s},-\mathrm{CH}_{3}\right), 0.87\left(\mathrm{~s},-\mathrm{CH}_{3}\right), 0.86\left(\mathrm{~s},-\mathrm{CH}_{3}\right), 0.84\left(\mathrm{~s},-\mathrm{CH}_{3}\right)$, $0.83\left(\mathrm{~s},-\mathrm{CH}_{3}\right) .{ }^{13} \mathrm{C}-\mathrm{NMR}\left(\mathrm{CDCl}_{3}, 150 \mathrm{MHz}\right) \delta 172.27,155.96,86.73,85.65,82.26,79.83,71.15$, $70.31,59.11,56.29,52.23,50.64,49.61,48.18,39.99,38.80,38.10,37.27,34.98,32.83,31.56$, $31.42,28.81,28.57$ ( $\times 3 \mathrm{C}), 28.25,28.13,27.81,26.36,25.22,23.98,19.54,18.37(\times 3 C), 17.43$, 16.77, 16.57, 15.62. HR-MS (ESI, $\mathrm{m} / \mathrm{z}$ ) $[\mathrm{M}+\mathrm{H}]^{+}$calcd. for $\mathrm{C}_{40} \mathrm{H}_{69} \mathrm{NO}_{7}, 676.5152$, found: 676.5156.

(20S, 24R)-Epoxy-3 $\beta$-O-(Boc-L-alanyl)-dammarane-6 $\alpha, 12 \beta, 25$-triol (3a)

White powder (yield 56.8\%), ${ }^{1} \mathrm{H}-\mathrm{NMR}\left(\mathrm{CDCl}_{3}, 600 \mathrm{MHz}\right) \delta 5.35(\mathrm{td}, J=10.5,4.5 \mathrm{~Hz}$, $1 \mathrm{H}), 4.92(\mathrm{~s}, 1 \mathrm{H}), 4.46-4.43(\mathrm{~m}, 1 \mathrm{H}), 3.84-3.81(\mathrm{dd}, J=8.7,6.8 \mathrm{~Hz}, 1 \mathrm{H}), 3.52-3.47(\mathrm{~m}, 1 \mathrm{H})$, $3.36(\mathrm{~s}, 1 \mathrm{H}), 2.51-2.45(\mathrm{~m}, 4 \mathrm{H}), 2.19-2.15(\mathrm{~m}, 1 \mathrm{H}), 2.02-1.81(\mathrm{~m}, 4 \mathrm{H}), 1.65-1.50(\mathrm{~m}, 6 \mathrm{H})$, 
$1.41\left(\mathrm{~s}, 4 \times-\mathrm{CH}_{3}\right), 1.32-1.27(\mathrm{~m}, 2 \mathrm{H}), 1.25\left(\mathrm{~s},-\mathrm{CH}_{3}\right), 1.24\left(\mathrm{~s},-\mathrm{CH}_{3}\right), 1.14-1.11(\mathrm{~m}, 2 \mathrm{H}), 1.10$ $\left(\mathrm{s},-\mathrm{CH}_{3}\right), 1.07\left(\mathrm{~s},-\mathrm{CH}_{3}\right), 1.04-1.03(\mathrm{~m}, 1 \mathrm{H}), 0.97\left(\mathrm{~s},-\mathrm{CH}_{3}\right), 0.96\left(\mathrm{~s},-\mathrm{CH}_{3}\right), 0.90\left(\mathrm{~s},-\mathrm{CH}_{3}\right), 0.88$ $\left(\mathrm{s},-\mathrm{CH}_{3}\right) .{ }^{13} \mathrm{C}-\mathrm{NMR}\left(\mathrm{CDCl}_{3}, 150 \mathrm{MHz}\right) \delta 172.33,155.90,86.60,85.60,80.71,79.51,71.09$, $70.81,70.27,61.48,58.97,51.98,50.02,49.14,47.99,42.62,40.86,39.41,38.35,37.87,35.03$, $32.75,31.34,30.59,28.70,28.54(\times 3 C), 28.04,27.66,26.29,25.10,23.42,18.22,17.62,17.51$, 16.91, 16.75.HR-MS (ESI, $\mathrm{m} / \mathrm{z}$ ) [M + H] ${ }^{+}$calcd. for $\mathrm{C}_{38} \mathrm{H}_{65} \mathrm{NO}_{8}, 664.4788$, found: 664.4785 .

(20S, 24R)-Epoxy-3 $\beta$-O-(Boc-L-methinyl)-dammarane-6 $\alpha, 12 \beta, 25$-triol (3b)

Yellow powder (yield 63.4\%), ${ }^{1} \mathrm{H}-\mathrm{NMR}\left(\mathrm{CDCl}_{3}, 600 \mathrm{MHz}\right) \delta 5.59(\mathrm{~s}, 1 \mathrm{H}), 5.37-5.29$ $(\mathrm{m}, 1 \mathrm{H}), 5.06(\mathrm{~s}, 1 \mathrm{H}), 4.50-4.47(\mathrm{~m}, 1 \mathrm{H}), 4.41-4.32(\mathrm{~m}, 1 \mathrm{H}), 3.84-3.81(\mathrm{~m}, 1 \mathrm{H}), 3.51-3.46$ $(\mathrm{m}, 1 \mathrm{H}), 2.54-2.51(\mathrm{~m}, 2 \mathrm{H}), 2.31-2.27(\mathrm{~m}, 2 \mathrm{H}), 2.12-2.09(\mathrm{~m}, 2 \mathrm{H}), 2.07\left(\mathrm{~s},-\mathrm{SCH}_{3}\right), 1.72-1.62$ $(\mathrm{m}, 5 \mathrm{H}), 1.52-1.48(\mathrm{~m}, 5 \mathrm{H}), 1.42\left(\mathrm{~s}, 3 \times-\mathrm{CH}_{3}\right), 1.31-1.29(\mathrm{~m}, 5 \mathrm{H}), 1.24\left(\mathrm{~d}, J=2.8 \mathrm{~Hz}, 2 \times-\mathrm{CH}_{3}\right)$, $1.24\left(\mathrm{~s},-\mathrm{CH}_{3}\right), 1.09\left(\mathrm{~s},-\mathrm{CH}_{3}\right), 1.07\left(\mathrm{~s},-\mathrm{CH}_{3}\right), 1.04-1.00(\mathrm{~m}, 2 \mathrm{H}), 0.99\left(\mathrm{~s},-\mathrm{CH}_{3}\right), 0.97\left(\mathrm{~s},-\mathrm{CH}_{3}\right)$, 0.95-0.93 $(\mathrm{m}, 1 \mathrm{H}), 0.90\left(\mathrm{~d}, J=4.2 \mathrm{~Hz}, 2 \times-\mathrm{CH}_{3}\right) .{ }^{13} \mathrm{C}-\mathrm{NMR}\left(\mathrm{CDCl}_{3}, 150 \mathrm{MHz}\right) \delta 172.19,155.49$, 86.60, 85.58, 81.87, 80.12, 70.82, 70.57, 70.28, 58.94, 53.37, 51.97, 50.01, 49.11, 47.98, 42.57, $40.77,39.32,38.29,34.12,32.73,32.51,31.33,30.58,30.18,28.70,28.46(\times 3 C), 28.03,27.66$, 26.26, 25.10, 23.37, 18.20, 17.49, 16.97, 16.73, 15.62. HR-MS (ESI, m/z) $[\mathrm{M}+\mathrm{H}]^{+}$calcd. for $\mathrm{C}_{40} \mathrm{H}_{69} \mathrm{NO}_{8} \mathrm{~S}, 724.4822$, found:724.4827.

(20S, 24R)-Epoxy-3 $\beta$-O-(Boc-L-glycyl)-dammarane-6 $\alpha, 12 \beta, 25$-triol (3c)

White powder (yield $51.6 \%),{ }^{1} \mathrm{H}-\mathrm{NMR}\left(\mathrm{CDCl}_{3}, 600 \mathrm{MHz}\right) \delta 5.60(\mathrm{~s}, 1 \mathrm{H}), 5.00(\mathrm{~s}, 1 \mathrm{H})$, 4.52-4.49 (m, 1H), 4.12-4.09 (m, 1H), 3.91-3.90 (m, 2H), 3.85-3.83 (m, 1H), 3.53-3.48 (m, $1 \mathrm{H})$, 2.21-2.17 (m, 1H), 2.07-1.96 (m, 3H), 1.93-1.80 (m, 4H), 1.72-1.65 (m, 5H), $1.62\left(\mathrm{~s},-\mathrm{CH}_{3}\right)$, $1.58-1.49(\mathrm{~m}, 3 \mathrm{H}), 1.45\left(\mathrm{~s}, 3 \times-\mathrm{CH}_{3}\right), 1.33-1.29(\mathrm{~m}, 2 \mathrm{H}), 1.27\left(\mathrm{~s},-\mathrm{CH}_{3}\right), 1.26\left(\mathrm{~s},-\mathrm{CH}_{3}\right), 1.16$ $\left(\mathrm{s},-\mathrm{CH}_{3}\right), 1.09\left(\mathrm{~s},-\mathrm{CH}_{3}\right), 1.05\left(\mathrm{~s},-\mathrm{CH}_{3}\right), 0.98-0.97(\mathrm{~m}, 2 \mathrm{H}), 0.93\left(\mathrm{~s},-\mathrm{CH}_{3}\right), 0.92\left(\mathrm{~s},-\mathrm{CH}_{3}\right)$. ${ }^{13} \mathrm{C}-\mathrm{NMR}\left(\mathrm{CDCl}_{3}, 150 \mathrm{MHz}\right) \delta 170.20,155.64,86.48,85.44,81.95,79.93,70.79,70.14,68.35$, 61.30, 51.81, 49.89, 49.0, 47.88, 47.05, 42.67, 40.88 38.94, 38.33, 38.20, 32.60, 31.24, 31.19, 30.68, 28.58, 28.33 ( $\times 3 \mathrm{C}), 27.89,27.53,26.13,24.95,23.34,18.10,17.48,16.93,16.49$. HR-MS (ESI, $\mathrm{m} / \mathrm{z})[\mathrm{M}+\mathrm{H}]^{+}$calcd. for $\mathrm{C}_{37} \mathrm{H}_{63} \mathrm{NO}_{8}, 650.4632$, found: 650.4631 .

(20S, 24R)-Epoxy-3 $\beta$-O-(Boc-L-leucyl)-dammarane- $6 \alpha, 12 \beta, 25$-triol (3d)

Light yellow powder (yield 43.8\%), ${ }^{1} \mathrm{H}-\mathrm{NMR}\left(\mathrm{CDCl}_{3}, 600 \mathrm{MHz}\right) \delta 5.69(\mathrm{~s}, 1 \mathrm{H}), 5.25$ $(\mathrm{s}, 1 \mathrm{H}), 4.89(\mathrm{~s}, 1 \mathrm{H}),, 4.40-4.36(\mathrm{~m}, 1 \mathrm{H}), 4.06(\mathrm{~d}, J=11.1 \mathrm{~Hz}, 1 \mathrm{H}), 3.88-3.85(\mathrm{~m}, 1 \mathrm{H}), 3.55-3.49$ $(\mathrm{m}, 1 \mathrm{H}), 3.22-3.20(\mathrm{~m}, 1 \mathrm{H}), 2.23-2.19(\mathrm{~m}, 1 \mathrm{H}), 2.15(\mathrm{~m}, 3 \mathrm{H}), 1.94-1.83(\mathrm{~m}, 6 \mathrm{H}), 1.71-1.59$ $(\mathrm{m}, 9 \mathrm{H}), 1.46\left(\mathrm{~s}, 3 \times-\mathrm{CH}_{3}\right), 1.36\left(\mathrm{~s},-\mathrm{CH}_{3}\right), 1.35\left(\mathrm{~s},-\mathrm{CH}_{3}\right), 1.33-1.31(\mathrm{~m}, 1 \mathrm{H}), 1.29\left(\mathrm{~s},-\mathrm{CH}_{3}\right)$, $1.18\left(\mathrm{~s},-\mathrm{CH}_{3}\right), 1.11\left(\mathrm{~s},-\mathrm{CH}_{3}\right), 1.09\left(\mathrm{~s},-\mathrm{CH}_{3}\right), 1.05-1.03(\mathrm{~m}, 3 \mathrm{H}), 0.97\left(\mathrm{~s},-\mathrm{CH}_{3}\right), 0.96\left(\mathrm{~s},-\mathrm{CH}_{3}\right)$, $0.92\left(\mathrm{~s},-\mathrm{CH}_{3}\right), 0.90\left(\mathrm{~s},-\mathrm{CH}_{3}\right) .{ }^{13} \mathrm{C}-\mathrm{NMR}\left(\mathrm{CDCl}_{3}, 150 \mathrm{MHz}\right) \delta$ 172.79, 155.75, 86.62, 85.57, 81.76, 78.80, 77.37, 72.41, 70.34, 68.53, 61.50, 56.09, 52.29, 50.39, 49.14, 48.63, 47.19, 42.14, $39.95,39.15,38.44,37.27,32.74,31.93,31.60,30.90,28.72,28.52(\times 3 C), 28.15,27.56,26.87$, $26.27,25.09,24.91,22.98,22.20,18.18,17.57,17.08,16.40$. HR-MS (ESI, $\mathrm{m} / \mathrm{z}$ ) $[\mathrm{M}+\mathrm{H}]^{+}$calcd. for $\mathrm{C}_{41} \mathrm{H}_{71} \mathrm{NO}_{8}, 706.5258$, found:706.5255.

(20S, 24R)-Epoxy-3 $\beta$-O-(Boc-L-prolyl)-dammarane-6 $\alpha, 12 \beta, 25$-triol (3e).

Light yellow powder (yield 69.1\%), ${ }^{1} \mathrm{H}-\mathrm{NMR}\left(\mathrm{CDCl}_{3}, 600 \mathrm{MHz}\right) \delta 5.32(\mathrm{~s}, 1 \mathrm{H}), 4.53$ $4.48(\mathrm{~m}, 1 \mathrm{H}), 4.22(\mathrm{~m}, 1 \mathrm{H}), 4.27-4.26(\mathrm{~m}, 1 \mathrm{H}), 4.20-4.09(\mathrm{~m}, 1 \mathrm{H}), 3.88-3.86(\mathrm{~m}, 1 \mathrm{H}), 3.54-3.48$ $(\mathrm{m}, 1 \mathrm{H}), 2.23-2.19(\mathrm{~m}, 2 \mathrm{H}), 2.05-1.86(\mathrm{~m}, 10 \mathrm{H}), 1.76-1.55(\mathrm{~m}, 10 \mathrm{H}), 1.46\left(\mathrm{~s},-\mathrm{CH}_{3}\right), 1.44$ $\left(\mathrm{s}, 3 \times-\mathrm{CH}_{3}\right), 1.36-1.34(\mathrm{~m}, 2 \mathrm{H}), 1.29\left(\mathrm{~s}, 2 \times-\mathrm{CH}_{3}\right), 1.19-1.05(\mathrm{~m}, 1 \mathrm{H}), 1.11\left(\mathrm{~s},-\mathrm{CH}_{3}\right), 1.09$ $\left(\mathrm{s},-\mathrm{CH}_{3}\right), 1.02\left(\mathrm{~s},-\mathrm{CH}_{3}\right), 0.93\left(\mathrm{~s},-\mathrm{CH}_{3}\right), 0.90\left(\mathrm{~s},-\mathrm{CH}_{3}\right) .{ }^{13} \mathrm{C}-\mathrm{NMR}\left(\mathrm{CDCl}_{3}, 150 \mathrm{MHz}\right) \delta 172.98$, $153.98,86.60,85.60,80.85,80.08,72.33,70.79,70.28,59.53,58.93,52.00,50.16,49.13,47.95$, $46.61,46.41,42.77,41.04,39.56,38.27,32.77,31.35,30.58,30.29,29.82,28.74,28.60,28.04$ ( $\times 3 \mathrm{C}), 27.68,26.28,25.11,24.48,23.61,18.25,17.59,17.41,16.75$. HR-MS (ESI, m/z) [M + $\mathrm{H}]^{+}$calcd. for $\mathrm{C}_{40} \mathrm{H}_{67} \mathrm{NO}_{8}, 690.4945$, found:690.4941.

(20S, 24R)-Epoxy-3 $\beta$-O-(Boc-L-valyl)-dammarane- $6 \alpha, 12 \beta, 25$-triol (3f)

White powder (yield $52.3 \%),{ }^{1} \mathrm{H}-\mathrm{NMR}\left(\mathrm{CDCl}_{3}, 600 \mathrm{MHz}\right) \delta 5.38-5.34(\mathrm{td}, J=10.5$, $4.5 \mathrm{~Hz}, 1 \mathrm{H}), 4.95(\mathrm{~s}, 1 \mathrm{H}), 4.48-4.45(\mathrm{~m}, 1 \mathrm{H}), 4.21-4.18(\mathrm{~m}, 1 \mathrm{H}), 3.84-3.81(\mathrm{~m}, 1 \mathrm{H}), 3.51-3.47$ $(\mathrm{m}, 1 \mathrm{H}), 2.18-2.14(\mathrm{~m}, 2 \mathrm{H}), 2.02-1.79(\mathrm{~m}, 6 \mathrm{H}), 1.73-1.48(\mathrm{~m}, 10 \mathrm{H}), 1.41\left(\mathrm{~s}, 3 \times-\mathrm{CH}_{3}\right), 1.40$ $\left(\mathrm{s}, 2 \times-\mathrm{CH}_{3}\right), 1.32-1.29(\mathrm{~m}, 2 \mathrm{H}), 1.25\left(\mathrm{~s},-\mathrm{CH}_{3}\right), 1.24\left(\mathrm{~s},-\mathrm{CH}_{3}\right), 1.10\left(\mathrm{~s},-\mathrm{CH}_{3}\right), 1.07\left(\mathrm{~s},-\mathrm{CH}_{3}\right)$, $1.02\left(\mathrm{~s},-\mathrm{CH}_{3}\right), 0.98\left(\mathrm{~s},-\mathrm{CH}_{3}\right), 0.95\left(\mathrm{~s},-\mathrm{CH}_{3}\right), 0.93-0.91(\mathrm{~m}, 1 \mathrm{H}), 0.89\left(\mathrm{~s},-\mathrm{CH}_{3}\right) .{ }^{13} \mathrm{C}-\mathrm{NMR}$ 
$\left(\mathrm{CDCl}_{3}, 150 \mathrm{MHz}\right) \delta 172.28,155.87,86.60,85.60,81.78,79.83,72.77,72.20,70.79,70.28,58.93$, $51.97,49.14,47.97,42.63,40.99,39.57,38.34,37.78,32.73,31.33(\times 2 C), 31.22,30.88,30.60$, $28.69,28.47$ (×3C), 28.03, 27.65, 26.28, 25.09, 23.35, 19.70, 19.51, 18.20, 17.45, 16.94, 16.71. HR-MS (ESI, m/z) [M + H] $]^{+}$calcd. for $\mathrm{C}_{40} \mathrm{H}_{69} \mathrm{NO}_{8}, 692.5101$, found: 692.5104 .

\subsubsection{Synthesis of Compounds $\mathbf{2} \mathbf{a}-\mathbf{2} \mathbf{f}$ and $\mathbf{4 a} \mathbf{a}-\mathbf{4 f}$}

At room temperature, the intermediate of $N$-Boc-amino acids conjugated pyxinol was directly dissolved in dry $\mathrm{CH}_{2} \mathrm{Cl}_{2}(5 \mathrm{~mL})$, TFA $(2 \mathrm{~mL})$ was then added gently, and the mixture was stirred for $2 \mathrm{~h}$. The reaction solution was washed with $\mathrm{NaHCO}_{3}$, water, and saturated brine, dried $\left(\mathrm{MgSO}_{4}\right)$, filtered, and concentrated. The concentrated residue was purified by silica gel to afford corresponding conjugate $\mathbf{2 a}-\mathbf{2} \mathbf{f}$, dichloromethane and methanol (60:1-15:1) were used as eluting solvents. The $\mathbf{4 a}-\mathbf{4 f}$ were obtained by the same procedure described above, except the volume of eluting solvents dichloromethane and methanol are 30:1-5:1.

(20S, 24R)-Epoxy-3 $\beta$-O-(L-alanyl)-dammarane-12 $\beta$, 25-diol (2a)

Light yellow powder (yield 91.8\%), ${ }^{1} \mathrm{H}-\mathrm{NMR}$ (Pyridin- $\left.\mathrm{d}_{5}, 600 \mathrm{MHz}\right) \delta 5.83(\mathrm{~s}, 1 \mathrm{H})$, $4.89(\mathrm{~s}, 1 \mathrm{H}), 4.74(\mathrm{dd}, J=10.9,5.7 \mathrm{~Hz}, 1 \mathrm{H}), 4.03-3.99(\mathrm{~m}, 1 \mathrm{H}), 3.82-3.73(\mathrm{~m}, 2 \mathrm{H}), 2.32-2.18$ $(\mathrm{m}, 2 \mathrm{H}), 2.03-1.84(\mathrm{~m}, 5 \mathrm{H}), 1.69-1.57(\mathrm{~m}, 5 \mathrm{H}), 1.54\left(\mathrm{~s},-\mathrm{CH}_{3}\right), 1.50\left(\mathrm{~s},-\mathrm{CH}_{3}\right), 1.49-1.47$ $(\mathrm{m}, 2 \mathrm{H}), 1.45-1.35(\mathrm{~m}, 4 \mathrm{H}), 1.34\left(\mathrm{~s},-\mathrm{CH}_{3}\right), 1.32\left(\mathrm{~s},-\mathrm{CH}_{3}\right), 1.29-1.27(\mathrm{~m}, 2 \mathrm{H}), 1.12-1.08(\mathrm{~m}$, $1 \mathrm{H}), 1.03\left(\mathrm{~s},-\mathrm{CH}_{3}\right), 0.95\left(\mathrm{~s},-\mathrm{CH}_{3}\right), 0.94\left(\mathrm{~s},-\mathrm{CH}_{3}\right), 0.93\left(\mathrm{~s},-\mathrm{CH}_{3}\right), 0.90-0.86(\mathrm{~m}, 1 \mathrm{H}), 0.81(\mathrm{~s}$, $\left.-\mathrm{CH}_{3}\right) .{ }^{13} \mathrm{C}-\mathrm{NMR}\left(\right.$ Pyridin-d $\left.\mathrm{d}_{5}, 150 \mathrm{MHz}\right) \delta$ 177.01, 87.09, 86.03, 81.10, 71.41, 70.69, 56.45, $52.53,51.41,50.96,50.15,48.75,40.35,38.99,38.61,37.52,35.34,33.19,32.79,32.07,29.15$, $28.44,28.08,27.64,27.33,25.89,24.31,21.71,18.78,18.70,17.09,16.82,15.89$. HR-MS (ESI, $\mathrm{m} / \mathrm{z})[\mathrm{M}+\mathrm{H}]^{+}$calcd. for $\mathrm{C}_{33} \mathrm{H}_{57} \mathrm{NO}_{5}, 548.4315$, found: 548.4317 .

(20S, 24R)-Epoxy-3 $\beta$-O-(L-methinyl)-dammarane-12 $\beta$, 25-diol (2b).

Yellow powder (yield 82.3\%), ${ }^{1} \mathrm{H}-\mathrm{NMR}\left(\mathrm{CDCl}_{3}, 600 \mathrm{MHz}\right) \delta 5.55(\mathrm{~s}, 1 \mathrm{H}), 4.51-4.49(\mathrm{~m}$, $1 \mathrm{H}), 3.83-3.81(\mathrm{~m}, 1 \mathrm{H}), 3.60-3.58(\mathrm{~m}, 1 \mathrm{H}), 3.51-3.46(\mathrm{~m}, 1 \mathrm{H}), 2.64-2.62(\mathrm{~m}, 2 \mathrm{H}), 2.18-2.14(\mathrm{~m}$, $1 \mathrm{H}), 2.08\left(\mathrm{~s},-\mathrm{CH}_{3}\right), 2.07-1.93(\mathrm{~m}, 5 \mathrm{H}), 1.86-1.83(\mathrm{~m}, 4 \mathrm{H}), 1.71-1.69(\mathrm{~m}, 1 \mathrm{H}), 1.66-1.60(\mathrm{~m}$, $4 \mathrm{H}), 1.56-1.50(\mathrm{~m}, 2 \mathrm{H}), 1.47-1.42(\mathrm{~m}, 3 \mathrm{H}), 1.29-1.27(\mathrm{~m}, 2 \mathrm{H}), 1.25\left(\mathrm{~s},-\mathrm{CH}_{3}\right), 1.24\left(\mathrm{~s},-\mathrm{CH}_{3}\right)$, 111-1.09 (m,1H), $1.07\left(\mathrm{~s},-\mathrm{CH}_{3}\right), 1.05-1.02(\mathrm{~m}, 1 \mathrm{H}), 0.96\left(\mathrm{~s},-\mathrm{CH}_{3}\right), 0.88\left(\mathrm{~s},-\mathrm{CH}_{3}\right), 0.86(\mathrm{~s}$, $\left.-\mathrm{CH}_{3}\right), 0.84\left(\mathrm{~s},-\mathrm{CH}_{3}\right), 0.82\left(\mathrm{~s},-\mathrm{CH}_{3}\right) .{ }^{13} \mathrm{C}-\mathrm{NMR}\left(\mathrm{CDCl}_{3}, 150 \mathrm{MHz}\right) \delta 175.47,86.93,85.85$, $82.20,71.35,70.52,56.48,54.04,52.44,50.85,49.83,48.39,40.26,39.02,38.43,37.50,35.17$, $34.11,33.04,31.78,31.63,30.93,30.12,28.56,28.34,28.02,26.57,25.43,24.14,18.59,18.57$, 17.00, 16.79, 15.83, 15.75. HR-MS (ESI, $\mathrm{m} / \mathrm{z}$ ) $[\mathrm{M}+\mathrm{H}]^{+}$calcd. for $\mathrm{C}_{35} \mathrm{H}_{61} \mathrm{NO}_{5}, 608.4348$, found: 608.4350 .

(20S, 24R)-Epoxy-3 $\beta$-O-(L-glycyl)-dammarane-12 $\beta, 25$-diol (2c)

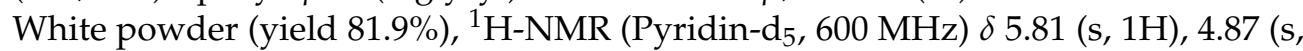
$1 \mathrm{H}), 4.73(\mathrm{dd}, J=11.5,4.9 \mathrm{~Hz}, 1 \mathrm{H}), 4.00-3.97(\mathrm{~m}, 1 \mathrm{H}), 3.92-3.87(\mathrm{~m}, 1 \mathrm{H}), 3.76-3.66(\mathrm{~m}, 2 \mathrm{H})$, 2.29-2.15 (m, 2H), 2.00-1.81 (m, 5H), 1.69-1.52 (m, 5H), $1.51\left(\mathrm{~s},-\mathrm{CH}_{3}\right), 1.48-1.33(\mathrm{~m}, 5 \mathrm{H})$, $1.31\left(\mathrm{~s},-\mathrm{CH}_{3}\right), 1.29\left(\mathrm{~s},-\mathrm{CH}_{3}\right), 1.27-1.24(\mathrm{~m}, 2 \mathrm{H}), 1.09-1.04(\mathrm{~m}, 2 \mathrm{H}), 1.00\left(\mathrm{~s},-\mathrm{CH}_{3}\right), 0.93(\mathrm{~s}$, $\left.-\mathrm{CH}_{3}\right), 0.89\left(\mathrm{~s},-\mathrm{CH}_{3}\right), 0.88\left(\mathrm{~s},-\mathrm{CH}_{3}\right), 0.85-0.82(\mathrm{~m}, 1 \mathrm{H}), 0.79\left(\mathrm{~s},-\mathrm{CH}_{3}\right) .{ }^{13} \mathrm{C}-\mathrm{NMR}$ (Pyridin-d5, $150 \mathrm{MHz}) \delta 174.94,87.08,86.02,81.31,71.41,70.69,56.48,52.53,50.97,50.14,48.75,45.19$, $40.35,39.02,38.51,37.51,35.34,33.18,32.79,32.07,29.15,28.39,28.07,27.63,27.33,25.89$, $24.35,18.80,18.70,17.02,16.84,15.88$. HR-MS (ESI, m/z) $[\mathrm{M}+\mathrm{H}]^{+}$calcd. for $\mathrm{C}_{32} \mathrm{H}_{55} \mathrm{NO}_{5}$, 534.4158, found: 534.4155 .

(20S, 24R)-Epoxy-3 $\beta$-O-(L-leucyl)-dammarane-12 $\beta, 25$-diol (2d)

Light yellow powder (yield 73.1\%), ${ }^{1} \mathrm{H}-\mathrm{NMR}\left(\mathrm{CDCl}_{3}, 600 \mathrm{MHz}\right) \delta 5.58(\mathrm{~s}, 1 \mathrm{H})$, 4.52-4.49 (m, 1H), 3.85-3.83 (m, 1H), 3.53-3.51 (m, 1H), 3.51-3.46 (m, 1H), 2.21-2.17 (m, 1H), $2.07-1.77(\mathrm{~m}, 10 \mathrm{H}), 1.73-1.1 .64(\mathrm{~m}, 5 \mathrm{H}), 1.58-1.53(\mathrm{~m}, 3 \mathrm{H}), 1.49-1.44(\mathrm{~m}, 3 \mathrm{H}), 1.31-1.29(\mathrm{~m}$, $2 \mathrm{H}), 1.27\left(\mathrm{~s},-\mathrm{CH}_{3}\right), 1.26\left(\mathrm{~s},-\mathrm{CH}_{3}\right), 1.13-1.11(\mathrm{~m}, 1 \mathrm{H}), 1.09\left(\mathrm{~s},-\mathrm{CH}_{3}\right), 0.98\left(\mathrm{~s},-\mathrm{CH}_{3}\right), 0.94(\mathrm{dd}$, $\left.J=9.6,6.6, \mathrm{~Hz}, 2 \times-\mathrm{CH}_{3}\right), 0.90\left(\mathrm{~s},-\mathrm{CH}_{3}\right), 0.88\left(\mathrm{~s},-\mathrm{CH}_{3}\right), 0.86\left(\mathrm{~s}, \mathrm{CH}_{3}\right), 0.85\left(\mathrm{~s},-\mathrm{CH}_{3}\right) .{ }^{13} \mathrm{C}-$ $\mathrm{NMR}\left(\mathrm{CDCl}_{3}, 150 \mathrm{MHz}\right) \delta 176.06,86.65,85.56,81.57,71.09,70.25,56.23,53.35,52.17,50.57$, $49.54,48.11,44.05,39.92,38.74,38.14,37.23,34.91,32.75,31.50,31.34,28.74,28.22,28.06$, 
27.73, 26.29, 25.15, 25.00, 23.84, 23.15, 21.99, 18.32, 18.28, 16.68, 16.51, 15.54. HR-MS (ESI, $\mathrm{m} / \mathrm{z})[\mathrm{M}+\mathrm{H}]^{+}$calcd. for $\mathrm{C}_{36} \mathrm{H}_{63} \mathrm{NO}_{5}, 590.4784$, found: 590.4789 .

(20S, 24R)-Epoxy-3 $\beta$-O-(L-prolyl)-dammarane-12 $\beta$, 25-diol (2e)

Light yellow powder (yield 83.5\%), ${ }^{1} \mathrm{H}-\mathrm{NMR}\left(\mathrm{CDCl}_{3}, 600 \mathrm{MHz}\right) \delta 5.58(\mathrm{~s}, 1 \mathrm{H}), 4.54-451$ $(\mathrm{m}, 1 \mathrm{H}), 3.96(\mathrm{~s}, 1 \mathrm{H}), 3.84-3.81(\mathrm{~m}, 1 \mathrm{H}), 3.49(\mathrm{td}, J=10.5,4.6 \mathrm{~Hz}, 1 \mathrm{H}), 3.19-3.07(\mathrm{~m}, 2 \mathrm{H})$, 2.26-2.15 (m, 2H), 2.01-1.76 (m, 8H), 1.71-1.60 (m, 5H), 1.56-1.39 (m, 6H), 1.29-1.27 (m, 2H), $1.25\left(\mathrm{~s},-\mathrm{CH}_{3}\right), 1.24\left(\mathrm{~s},-\mathrm{CH}_{3}\right), 1.11-1.09(\mathrm{~m}, 1 \mathrm{H}), 1.08\left(\mathrm{~s},-\mathrm{CH}_{3}\right), 1.05-1.01(\mathrm{~m}, 2 \mathrm{H}), 0.96$ $\left(\mathrm{s},-\mathrm{CH}_{3}\right), 0.93-0.90(\mathrm{~m}, 1 \mathrm{H}), 0.88\left(\mathrm{~s},-\mathrm{CH}_{3}\right), 0.86\left(\mathrm{~s},-\mathrm{CH}_{3}\right), 0.84\left(\mathrm{~s},-\mathrm{CH}_{3}\right), 0.81\left(\mathrm{~s},-\mathrm{CH}_{3}\right)$. ${ }^{13} \mathrm{C}-\mathrm{NMR}\left(\mathrm{CDCl}_{3}, 150 \mathrm{MHz}\right) \delta 173.27,86.49,85.38,82.28,70.92,70.15,59.87,56.03,52.02$, 50.43, 49.36, 47.93, 46.65, 39.78, 38.57, 38.10, 37.09, 34.74, 32.63, 31.39, 31.19, 30.11, 28.59, $28.08,27.96,27.54,26.02,25.02,24.97,23.70,18.19,18.15,16.48,16.37,15.40$. HR-MS (ESI, $\mathrm{m} / \mathrm{z})[\mathrm{M}+\mathrm{H}]^{+}$calcd. for $\mathrm{C}_{35} \mathrm{H}_{59} \mathrm{NO}_{5}, 574.4471$, found: 574.4469 .

(20S, 24R)-Epoxy-3 $\beta$-O-(L-valyl)-dammarane-12 $\beta$, 25-diol (2f)

Light yellow powder (yield 72.7\%), ${ }^{1} \mathrm{H}-\mathrm{NMR}$ (Pyridin-d $\left.\mathrm{d}_{5}, 600 \mathrm{MHz}\right) \delta 5.82(\mathrm{~s}, 1 \mathrm{H})$, $4.87(\mathrm{~s}, 1 \mathrm{H}), 4.72(\mathrm{dd}, J=11.6,4.8 \mathrm{~Hz}, 1 \mathrm{H}), 4.01-3.98(\mathrm{~m}, 1 \mathrm{H}), 3.77-3.71(\mathrm{td}, J=10.4,4.6 \mathrm{~Hz}$, $1 \mathrm{H}), 3.52(\mathrm{~d}, J=4.9 \mathrm{~Hz}, 1 \mathrm{H}), 3.30-2.16(\mathrm{~m}, 3 \mathrm{H}), 2.03-1.82(\mathrm{~m}, 5 \mathrm{H}), 1.73-1.54(\mathrm{~m}, 6 \mathrm{H}), 1.52(\mathrm{~s}$, -CH3), 1.47-1.34 (m, 5H), $1.32\left(\mathrm{~s},-\mathrm{CH}_{3}\right), 1.30\left(\mathrm{~s},-\mathrm{CH}_{3}\right), 1.28-1.26(\mathrm{~m}, 2 \mathrm{H}), 1.12(\mathrm{~d}, J=6.8 \mathrm{~Hz}$, $\left.-\mathrm{CH}_{3}\right), 1.07\left(\mathrm{~d}, \mathrm{~J}=6.8 \mathrm{~Hz}-\mathrm{CH}_{3}\right), 1.02\left(\mathrm{~s},-\mathrm{CH}_{3}\right), 0.97\left(\mathrm{~s},-\mathrm{CH}_{3}\right), 0.94\left(\mathrm{~s}, 2 \times-\mathrm{CH}_{3}\right), 0.92-0.85$ (m, 2H), 0.82 (s, $\left.-\mathrm{CH}_{3}\right) .{ }^{13} \mathrm{C}-\mathrm{NMR}$ (Pyridin-d5, $\left.150 \mathrm{MHz}\right) \delta$ 176.02, 87.10, 86.04, 81.31, 71.42, 70.70, 61.38, 56.50, 52.55, 50.97, 50.16, 48.76, 40.37, 39.01, 38.50, 37.53, 35.37, 33.20, 32.93, $32.80,32.08,30.40,28.53,28.09,27.65,27.34,25.90,24.41,20.33,19.64,18.71,17.67,17.23$, 16.83, 15.91. HR-MS (ESI, $\mathrm{m} / \mathrm{z}$ ) $[\mathrm{M}+\mathrm{H}]^{+}$calcd. for $\mathrm{C}_{35} \mathrm{H}_{61} \mathrm{NO}_{5}, 576.4628$, found: 576.623.

(20S, 24R)-Epoxy-3 $\beta$-O-(L-alanyl)-dammarane- $6 \alpha, 12 \beta, 25$-triol (4a)

White powder (yield 53.1\%), ${ }^{1} \mathrm{H}-\mathrm{NMR}\left(\mathrm{CDCl}_{3}, 600 \mathrm{MHz}\right) \delta 5.64(\mathrm{~s}, 1 \mathrm{H}), 4.47-4.44(\mathrm{~m}$, $1 \mathrm{H}), 4.08-4.04(\mathrm{~m}, 1 \mathrm{H}), 3.83-3.81(\mathrm{~m}, 1 \mathrm{H}), 3.51-3.47(\mathrm{~m}, 1 \mathrm{H}), 3.16-3.14(\mathrm{~m}, 1 \mathrm{H}), 2.67(\mathrm{~s}, 2 \mathrm{H})$, 2.19-2.15 (m, 1H), 2.00-1.97 (m, 2H), 1.90-1.79 (m, 3H), 1.68-1.47 (m, 9H), $1.24\left(\mathrm{~s}, 3 \times-\mathrm{CH}_{3}\right)$, $1.13\left(\mathrm{~s},-\mathrm{CH}_{3}\right), 1.11-1.09(\mathrm{~m}, 1 \mathrm{H}), 1.07\left(\mathrm{~s},-\mathrm{CH}_{3}\right), 1.03\left(\mathrm{~s},-\mathrm{CH}_{3}\right), 1.02\left(\mathrm{~s},-\mathrm{CH}_{3}\right), 0.97-0.93(\mathrm{~m}$, $2 \mathrm{H}), 0.91\left(\mathrm{~s}, 2 \mathrm{x}-\mathrm{CH}_{3}\right) .{ }^{13} \mathrm{C}-\mathrm{NMR}\left(\mathrm{CDCl}_{3}, 150 \mathrm{MHz}\right) \delta 171.99,86.62,85.51,81.92,70.97,70.35$, $68.26,61.29,58.79,51.99,49.96,49.09,48.01,47.00,42.58,40.98,39.04,38.50,33.81,32.73$, $31.41,31.31,30.84,28.73,28.06,27.62,26.23,25.11,18.27,17.62,17.06,16.90,16.70$. HR-MS (ESI, $\mathrm{m} / \mathrm{z})[\mathrm{M}+\mathrm{H}]^{+}$calcd. for $\mathrm{C}_{33} \mathrm{H}_{57} \mathrm{NO}_{6}, 564.4264$, found: 564.4269 .

(20S, 24R)-Epoxy-3 $\beta$-O-(L-methinyl)-dammarane-6 $\alpha, 12 \beta, 25$-triol (4b)

Light yellow powder (yield 42.5\%), ${ }^{1} \mathrm{H}-\mathrm{NMR}\left(\mathrm{CDCl}_{3}, 600 \mathrm{MHz}\right) \delta 5.62(\mathrm{~s}, 1 \mathrm{H}), 5.39-5.34$ $(\mathrm{m}, 1 \mathrm{H}), 4.51-4.46(\mathrm{~m}, 1 \mathrm{H}), 3.84-3.81(\mathrm{~m}, 1 \mathrm{H}), 3.62-3.58(\mathrm{~m}, 1 \mathrm{H}), 3.52-3.47(\mathrm{~m}, 1 \mathrm{H}), 2.64-2.58$ $(\mathrm{m}, 2 \mathrm{H}), 2.08(\mathrm{~s}, 2 \mathrm{H}), 2.07\left(\mathrm{~s},-\mathrm{SCH}_{3}\right), 1.93-1.77(\mathrm{~m}, 8 \mathrm{H}), 1.66-1.50(\mathrm{~m}, 10 \mathrm{H}), 1.33-1.29(\mathrm{~m}$, $2 \mathrm{H}), 1.24\left(\mathrm{~s}, 2 \times-\mathrm{CH}_{3}\right), 1.11\left(\mathrm{~s},-\mathrm{CH}_{3}\right), 1.07\left(\mathrm{~s},-\mathrm{CH}_{3}\right), 1.03\left(\mathrm{~s},-\mathrm{CH}_{3}\right), 0.98\left(\mathrm{~s},-\mathrm{CH}_{3}\right), 0.91(\mathrm{~s}$, $\left.-\mathrm{CH}_{3}\right), 0.90\left(\mathrm{~s},-\mathrm{CH}_{3}\right) .{ }^{13} \mathrm{C}-\mathrm{NMR}\left(\mathrm{CDCl}_{3}, 150 \mathrm{MHz}\right) \delta 174.73,86.60,85.58,81.24,72.13,70.77$, $70.28,58.92,53.73,51.96,50.03,49.13,47.95,47.17,42.58,40.95,39.55,38.31,33.78,33.15$, $32.72,31.32,30.61,28.67,28.02,27.64,26.26,25.08,23.32,18.19,17.47,17.04,16.70,15.47$. HR-MS (ESI, m/z) $[\mathrm{M}+\mathrm{H}]^{+}$calcd. for $\mathrm{C}_{35} \mathrm{H}_{61} \mathrm{NO}_{6} \mathrm{~S}, 624.4298$, found: 624.4293 .

(20S, 24R)-Epoxy-3 $\beta$-O-(-L-glycyl)-dammarane-6 $\alpha, 12 \beta, 25$-triol (4c)

White powder (yield 59.1\%), ${ }^{1} \mathrm{H}-\mathrm{NMR}\left(\mathrm{CDCl}_{3}, 600 \mathrm{MHz}\right) \delta 5.62(\mathrm{~s}, 1 \mathrm{H}), 4.52-4.50(\mathrm{~m}$, $1 \mathrm{H}), 4.13-4.08(\mathrm{~m}, 1 \mathrm{H}), 3.86-3.83(\mathrm{~m}, 1 \mathrm{H}), 3.52-3.48(\mathrm{~m}, 1 \mathrm{H}), 3.46(\mathrm{~s}, 2 \mathrm{H}), 2.21-2.17(\mathrm{~m}, 1 \mathrm{H})$, 2.05-1.96 (m, 3H), 1.93-1.81 (m, 6H), 1.70-1.54 (m, 8H), $1.27\left(\mathrm{~s},-\mathrm{CH}_{3}\right), 1.26\left(\mathrm{~s},-\mathrm{CH}_{3}\right), 1.16(\mathrm{~s}$, $\left.-\mathrm{CH}_{3}\right), 1.09\left(\mathrm{~s},-\mathrm{CH}_{3}\right), 1.06\left(\mathrm{~s},-\mathrm{CH}_{3}\right), 1.04\left(\mathrm{~s},-\mathrm{CH}_{3}\right), 0.98(\mathrm{~s}, 1 \mathrm{H}), 0.97(\mathrm{~s}, 1 \mathrm{H}), 0.93\left(\mathrm{~s},-\mathrm{CH}_{3}\right)$, $0.93\left(\mathrm{~s},-\mathrm{CH}_{3}\right) .{ }^{13} \mathrm{C}-\mathrm{NMR}\left(\mathrm{CDCl}_{3}, 150 \mathrm{MHz}\right) \delta 73.40,86.48,85.43,81.62,70.80,70.14,68.30$, $61.29,51.82,49.89,49.00,47.88,47.03,43.73,40.87,38.94,38.38$ (×2C), 32.60, 31.25, 31.19, $30.70,28.58,27.90,27.52,26.13,24.95,23.39,18.12,17.49,16.93,16.53$. HR-MS (ESI, m/z) [M $+\mathrm{H}]^{+}$calcd. for $\mathrm{C}_{32} \mathrm{H}_{55} \mathrm{NO}_{6}, 550.4107$, found: 550.4112 .

(20S, 24R)-Epoxy-3 $\beta$-O-(L-leucyl)-dammarane-6 $\alpha, 12 \beta, 25$-triol (4d)

Light yellow powder (yield 34.2\%), ${ }^{1} \mathrm{H}-\mathrm{NMR}\left(\mathrm{CDCl}_{3}, 600 \mathrm{MHz}\right) \delta 5.64(\mathrm{~s}, 1 \mathrm{H}), 4.52-4.50$ (m, 1H), 4.16-4.11 (m, 1H), 3.88-3.85 (m, 1H), 3.68-3.66 (m, 1H), 3.56-3.51 (m, 1H), 2.23-2.19 $(\mathrm{m}, 1 \mathrm{H}), 2.06-2.01(\mathrm{~m}, 4 \mathrm{H}), 1.96-1.81(\mathrm{~m}, 6 \mathrm{H}), 1.74-1.52(\mathrm{~m}, 10 \mathrm{H}), 1.29\left(\mathrm{~s}, 2 \times-\mathrm{CH}_{3}\right), 1.27(\mathrm{~s}$, $\left.-\mathrm{CH}_{3}\right), 1.19\left(\mathrm{~s},-\mathrm{CH}_{3}\right), 1.11\left(\mathrm{~s},-\mathrm{CH}_{3}\right), 1.09\left(\mathrm{~s}, 2 \times-\mathrm{CH}_{3}\right), 1.01-0.99(\mathrm{~m}, 2 \mathrm{H}), 0.98\left(\mathrm{~s},-\mathrm{CH}_{3}\right), 0.96$ 
$\left(\mathrm{s},-\mathrm{CH}_{3}\right), 0.95\left(\mathrm{~s},-\mathrm{CH}_{3}\right) .{ }^{13} \mathrm{C}-\mathrm{NMR}\left(\mathrm{CDCl}_{3}, 150 \mathrm{MHz}\right) \delta 175.85,86.49,85.43,81.32,70.80$, $70.15,68.37,61.35,53.22,51.83,49.89$, 49.00, 47.89, 47.05, 43.77, 40.89, 38.96, 38.33, 37.11, $32.60,31.20,30.77,29.71,28.59,27.90,27.53,26.14,24.96,24.85,23.35,23.00,21.82,18.12$, 17.44, 16.94, 16.65. HR-MS (ESI, $\mathrm{m} / \mathrm{z}$ ) $[\mathrm{M}+\mathrm{H}]^{+}$calcd. for $\mathrm{C}_{36} \mathrm{H}_{63} \mathrm{NO}_{6}, 606.4733$, found: 606.4738 .

(20S, 24R)-Epoxy-3 $\beta$-O-(L-prolyl)-dammarane-6 $\alpha, 12 \beta, 25$-triol (4e)

White powder (yield 45.8\%), ${ }^{1} \mathrm{H}-\mathrm{NMR}\left(\mathrm{CDCl}_{3}, 600 \mathrm{MHz}\right) \delta 5.64(\mathrm{~s}, 1 \mathrm{H}), 5.40-5.35$ (m, $1 \mathrm{H}), 4.57-4.53(\mathrm{~m}, 1 \mathrm{H}), 4.03-4.00(\mathrm{~m}, 1 \mathrm{H}), 3.84-3.81(\mathrm{~m}, 1 \mathrm{H}), 3.51-3.46(\mathrm{~m}, 1 \mathrm{H}), 3.34-3.16$ $(\mathrm{m}, 2 \mathrm{H}), 2.37-2.24(\mathrm{~m}, 3 \mathrm{H}), 2.16(\mathrm{~s}, 1 \mathrm{H}), 2.04-1.83(\mathrm{~m}, 9 \mathrm{H}), 1.68-1.46(\mathrm{~m}, 10 \mathrm{H}), 1.33-1.30(\mathrm{~m}$, 2H), $1.24\left(\mathrm{~s}, 3 \mathrm{x}-\mathrm{CH}_{3}\right), 1.09\left(\mathrm{~s},-\mathrm{CH}_{3}\right), 1.07\left(\mathrm{~s},-\mathrm{CH}_{3}\right), 1.00\left(\mathrm{~s},-\mathrm{CH}_{3}\right), 0.97\left(\mathrm{~s},-\mathrm{CH}_{3}\right), 0.90$ (s, $\left.-\mathrm{CH}_{3}\right) .{ }^{13} \mathrm{C}-\mathrm{NMR}\left(\mathrm{CDCl}_{3}, 150 \mathrm{MHz}\right) \delta 171.59,86.58,85.52,82.66,73.73,70.72,70.34,67.91$, 59.74, 51.95, 49.98, 49.09, 47.93, 46.71, 46.37, 42.45, 40.98, 39.59, 38.27, 32.64, 31.33, 30.65, 29.84, 29.54, 28.70, 28.05, 27.59, 26.17, 25.10, 24.98, 24.54, 18.12, 17.47, 16.93, 16.69. HR-MS (ESI, $\mathrm{m} / \mathrm{z}$ ) $[\mathrm{M}+\mathrm{H}]^{+}$calcd. for $\mathrm{C}_{35} \mathrm{H}_{59} \mathrm{NO}_{6}, 590.4420$, found: 590.4423 .

(20S, 24R)-Epoxy-3 $\beta$-O-(L-valyl)-dammarane-6 $\alpha, 12 \beta, 25$-triol (4f)

White powder (yield 41.5\%), ${ }^{1} \mathrm{H}-\mathrm{NMR}\left(\mathrm{CDCl}_{3}, 600 \mathrm{MHz}\right) \delta 5.59(\mathrm{~s}, 1 \mathrm{H}), 5.30-5.24$ $(\mathrm{m}, 1 \mathrm{H}), 4.54-4.52(\mathrm{~m}, 1 \mathrm{H}), 3.87-3.85(\mathrm{~m}, 1 \mathrm{H}), 3.55-3.51(\mathrm{~m}, 1 \mathrm{H}), 3.30(\mathrm{~d}, J=4.5 \mathrm{~Hz} 1 \mathrm{H})$, 2.22-2.18 (m, 1H), 2.12-2.04 (m, 3H), 1.92-1.85 (m, 3H), 1.74-1.55 (m, 8H), 1.51-1.46 (m, 2H), 1.33-1.31 (m, 2H), $1.29\left(\mathrm{~s},-\mathrm{CH}_{3}\right), 1.28\left(\mathrm{~s},-\mathrm{CH}_{3}\right), 1.15-1.13(\mathrm{~m}, 1 \mathrm{H}), 1.11\left(\mathrm{~s},-\mathrm{CH}_{3}\right), 1.09-1.06$ $(\mathrm{m}, 1 \mathrm{H}), 1.03\left(\mathrm{~s},-\mathrm{CH}_{3}\right), 1.00\left(\mathrm{~s},-\mathrm{CH}_{3}\right), 0.91\left(\mathrm{~s},-\mathrm{CH}_{3}\right), 0.90\left(\mathrm{~s},-\mathrm{CH}_{3}\right), 0.88\left(\mathrm{~s},-\mathrm{CH}_{3}\right), 0.87(\mathrm{~s}$, $\left.-\mathrm{CH}_{3}\right) .{ }^{13} \mathrm{C}-\mathrm{NMR}\left(\mathrm{CDCl}_{3}, 150 \mathrm{MHz}\right) \delta 175.20,86.52,85.43,81.36,70.94,70.10,67.03,60.36$, $56.09,52.02,50.43,49.40,47.97,39.77,38.61,37.92,37.07,34.76,32.62,31.77,31.35,31.21$, $28.59,28.07,27.91,27.60,26.14,25.00,23.77,19.65,19.21,16.76,16.60,16.35,15.40$. HR-MS (ESI, $\mathrm{m} / \mathrm{z}$ ) $[\mathrm{M}+\mathrm{H}]^{+}$calcd. for $\mathrm{C}_{35} \mathrm{H}_{61} \mathrm{NO}_{6}, 592.4577$, found: 592.4572 .

\subsection{Cytotoxic Activity Determination on HepG2 Cells}

\subsubsection{Cell Culture}

Human hepatocellular liver carcinoma cell line (HepG2) were obtained from Institute of Biochemistry and Cell Biology, Academy of Science (Shanghai, China) and were authenticated using the STR profiling method. HepG2 cells were cultured in MDEM (Gibco, Waltham, MA, USA) supplemented with 10\% fetal bovine serum (FBS) and 1\% penicillin-streptomycin bubbled with $5 \% \mathrm{CO}_{2}$-enriched air at a temperature of $37{ }^{\circ} \mathrm{C}$ (Thermo Scientific, Waltham, MA, USA).

\subsubsection{Cell Viability Assay}

The cytotoxic effect of compounds on HepG2 cells was assessed by using CCK-8 method [81]. Briefly, HepG2 cells were cultured in 96-well plates at a density of $5 \times 10^{3}$ cells per well for $24 \mathrm{~h}$. Then, the cells were treated with test compounds at different concentrations of $0,6.25,12.5,25,50,100,200 \mu \mathrm{M}$ which dissolved in Dimethyl sulfoxide (DMSO) and incubated in $\mathrm{CO}_{2}$ incubator for $48 \mathrm{~h}\left(37{ }^{\circ} \mathrm{C}, 5 \% \mathrm{CO}_{2}\right)$. After incubation, $10 \mu \mathrm{L} \mathrm{CCK}-8$ ( $5 \mathrm{mg} / \mathrm{mL})$ was added to each well and then incubated for another $4 \mathrm{~h}$, then the OD value of each pore was measured at $450 \mathrm{~nm}$ by enzyme labeling instrument. Three replicates were performed. The relative cell viability was expressed as percentage relative to the untreated cells. The inhibition ratio was calculated. The $\mathrm{IC}_{50}$ values were calculated using Logistic regression from three independent tests.

\subsection{Effects of Compound 2e on H22 Tumor-Bearing Mice}

\subsubsection{Cell Lines and Animals}

Hepatocellular carcinoma cell line (H22) was purchased from the Cell Bank of Type Culture Collection Committee of Chinese Academy of Sciences (Shanghai, China), and cultured in Dulbecco's modified eagle medium supplemented with $10 \%$ fetal calf serum and then cultured at $37{ }^{\circ} \mathrm{C}$ in $5 \% \mathrm{CO}_{2}$.

Female and male Kunming mice (SPF grade, weighing 18-22 g) were purchased from Changchun Yisi Experimental Animal Technology Co., Ltd. (Changchun, China). All the 
mice, given food and water ad libitum, were raised in temperature and humidity controlled $\left(23 \pm 2{ }^{\circ} \mathrm{C}, 50 \pm 10 \%\right.$ humidity) environment under a $12 \mathrm{~h}$ light/dark cycle. The mice were acclimatized for at least 1 week before use. The animal experiments were performed in accordance with the guidelines for the Care and Use of Laboratory Animals and approved by the ethics committee of School of Pharmaceutical Sciences, Jilin University, China.

\subsubsection{Materials}

Cyclophosphamide (CTX), used as the positive drug, was purchased from Sigma (St. Lousis, MO, USA. Detecting kits for IL-2, TNF- $\alpha$, VEGF, AST, ALT, CRE and BUN were purchased from Nanjing Jiancheng Biotechnology Co. (Nanjing, China).

\subsubsection{Tumor-Bearing Mice Model and Drug Administration}

$\mathrm{H} 22$ cells, resuspended in normal saline with final concentration of $5 \times 10^{6}$ cells $/ \mathrm{mL}$, were injected into the abdominal cavity of mice under aseptic conditions. After 1 week, ascites tumor cells were extracted and dispersed with physiological saline to a concentration of $1 \times 10^{7}$ cells $/ \mathrm{mL}$.

The diluted ascites tumor cell suspension was then injected $\left(0.2 \mathrm{~mL}, 2 \times 10^{6}\right.$ cells/mouse) subcutaneously into the right forelimb armpit of mice at day 1 to establish the tumorbearing mice model. The mice did not injected the tumor cells were used as the normal control.

$24 \mathrm{~h}$ after transplanting the $\mathrm{H} 22$ cells, mice were divided into seven groups $(n=10)$ : (i) normal control group (N, physiological saline); (ii) tumor-bearing model group (M, physiological saline); (iii) cyclophosphamide positive drug group (CTX, $20 \mathrm{mg} / \mathrm{kg}$ ); (iv) low-dose compound $2 \mathbf{e}$ group (L-2e, $25 \mathrm{mg} / \mathrm{kg}$; (v) moderate-dose compound $2 \mathbf{e}$ group (M-2e, $50 \mathrm{mg} / \mathrm{kg}$ ); (vi) high dose compound 2e group (H-2e, $100 \mathrm{mg} / \mathrm{kg}$ ); (vii) compound $2 \mathbf{e}(50 \mathrm{mg} / \mathrm{kg})+\mathrm{CTX}(20 \mathrm{mg} / \mathrm{kg})$ combination group. Mice in each group were intragastrically administered once a day continuously for 14 days. Administration volume were all $20 \mathrm{~mL} / \mathrm{kg}$. CTX, L-2e, M-2e, H-2e and $\mathbf{2 e}+\mathrm{CTX}$ were respectively dissolved in physiological saline to form the aqueous solution with the corresponding concentrations.

\subsubsection{Antitumor Activity Evaluation}

Before administration every day, the tumor size and body weight were measured. When the tumor was larger than $20 \mathrm{~mm}$ in diameter, animals were euthanized according to the IACUC proposals.

$24 \mathrm{~h}$ after the last administration, the whole blood was collected from the orbit. Serum was obtained from whole blood by centrifugation ( $3500 \mathrm{rpm}, 15 \mathrm{~min}, 4^{\circ} \mathrm{C}$ ) and stored at $-20{ }^{\circ} \mathrm{C}$. The levels of IL-2, TNF- $\alpha$, VEGF, AST, ALT, BUN and CRE in serum were determined in accordance with the procedures described in commercial kit instructions.

Mice were then killed by cervical dislocation after blood collected. The tumor, liver and kidney were rapidly separated, weighted and dissected for histopathological examination.

The tumor inhibition rate (TIR) was calculated as follows: TIR $(\%)=\left(\mathrm{W}_{\mathrm{m}}-\mathrm{W}_{\mathrm{t}}\right) / \mathrm{W}_{\mathrm{m}} \times 100 \%$ $\left(\mathrm{W}_{\mathrm{m}}\right.$ : tumor weight of model group, $\mathrm{W}_{\mathrm{t}}$ : tumor weight of treatment group).

The liver and kidney indexes were calculated as follows: organ index $(\mathrm{mg} / \mathrm{g})=$ average weight of organ/average body weight.

The tissue of tumor, liver and kidney from each mouse was quickly fixed in $10 \%$ neutral-buffered formalin for histopathology. The H\&E staining of H22 solid tumor, liver and kidney tissue were embedded in paraffin and sectioned into sections with a thickness of $5 \mu \mathrm{m}$ which were conducted following the manufacturer's instructions in respective kit. Tumor, liver and kidney tissue sections were observed by light microscopy (Leica DM750, Solms, Germany) and recorded by photography $(\times 400)$. 


\subsubsection{Statistical Analysis}

The data were expressed as mean $\pm \mathrm{SD}$. All statistical analyses were performed using the SPSS 16.0 software (SPSS, USA). For statistical comparison of values, a Student's $t$-test was used, and $p<0.05$ was considered statistically significant. One-way ANOVA, followed by $t$-test, was used to compare differences among groups.

\subsection{Metabolomics Study}

\subsubsection{Materials}

From Sigma-Aldrich (St. Louis, MO, USA), formic acid, linoleic acid (purity $\geq 99 \%$ ) and arachidonic acid (purity $\geq 97 \%$ ) were purchased. From Fisher Chemical Company (Geel, Belgium), acetonitrile and methanol were obtained. Deionized water was prepared by Millipore water purification system (Millipore, Billerica, MA, USA). Paraxanthine (purity $\geq 7 \%$ ), Chloral hydrate, acetic acid (36-38\%) and L-tryptophan were purchased from Beijing Laiyao Biological Technology Co., Ltd. (Beijing, China), Biosharp Co., Ltd. (Shenyang, China), J\&K Technology Co., LTD. (Hong Kong, China) and the National Institutes for Food and Drug Control (Beijing, China), respectively.

\subsubsection{UPLC-QTOF-MS Conditions}

Waters UPLC system with electrospray ionization (ESI) interface combined with Xevo G2-XS QTOF mass spectrometer was applied for determination and analysis.

LC conditions were as follows: ACQUITY UPLC BEH C18 $(100 \times 2.1 \mathrm{~mm}, 1.7 \mu \mathrm{m})$ with column temperature being set as $30^{\circ} \mathrm{C}$; mobile phase consisting of $0.1 \%$ formic acid in water (eluent $\mathrm{A}$ ) and $0.1 \%$ formic acid in acetonitrile (eluent $\mathrm{B}$ ) with the elution conditions (0 min, $10 \%$ B; $2-26 \mathrm{~min}, 10 \% \rightarrow 90 \%$ B; $26-28 \mathrm{~min}, 90 \% \mathrm{~B} ; 28-28.1 \mathrm{~min}, 90 \% \rightarrow 10 \% \mathrm{~B}$; $28.1-30 \mathrm{~min}, 10 \% \mathrm{~B}$ ); flow rate at $0.4 \mathrm{~mL} / \mathrm{min} ; 10 \%$ and $90 \%$ acetonitrile aqueous solutions being used as weak and strong wash solvents, respectively; the temperature of sample manager being set at $10^{\circ} \mathrm{C}$.

MS conditions were as follows: desolvation and source temperatures being and $150{ }^{\circ} \mathrm{C}$, respectively; cone and desolvation gas flows being $50 \mathrm{~L} / \mathrm{h}$ and $800 \mathrm{~L} / \mathrm{h}$, respectively; cone voltage setting at $40 \mathrm{~V}$; capillary voltage being at $2.2 \mathrm{kV}$ (ESI-) and $2.6 \mathrm{kV}\left(\mathrm{ESI}+\right.$ ); $\mathrm{MS}^{\mathrm{E}}$ centroid mode with low energy of $6 \mathrm{~V}$ and high energy of $20 \sim 40 \mathrm{~V}$; sodium formate being used to calibrate the mass spectrometer in the range of 50 to $1200 \mathrm{Da}$; external reference leucine enkephalin (m/z 556.2771 and 554.2615 in ESI+ and ESI- modes) injected at a flow of $10 \mu \mathrm{L} / \mathrm{min}$.

QC sample was injected randomly throughout the whole worklist for 5 times. The volume injections of $\mathrm{QC}$ and test samples were all $5 \mu \mathrm{L}$ per run. MassLynx V4.1 workstation (Waters, Manchester, UK) was used to record data.

\subsubsection{Metabolomics Study}

Firstly, MarkerLynx XS software (Version 4.1, Waters Co., Milford, MA, USA) was applied to analyze data with the optimized parameters (mass range 50 1200 Da, mass tolerance 0.10 with window 0.10 , retention time $2 \sim 28 \mathrm{~min}$ with window 0.20 , noise elimination level 6 and marker intensity threshold 2000 counts). Then the results of exact mass/retention time pairs and the corresponding intensities were shown in Extended Statistics (XS) Viewer.

Secondly, SIMCA-P software (Version 14.1, Umetric, Umea, Sweden) was used to perform the multivariate analysis including principal component analysis (PCA) and orthogonal projections to latent structures discriminant analysis (OPLS-DA) [34]. S-plots were then created to explore the remarkable potential biomarkers with VIP (variable importance in the projection) value above 1.0 and $p$-value below 0.05 . In addition, the permutation test with $\mathrm{R}^{2} / \mathrm{Q}^{2}$ values indicating statistical significance was performed to provide a reference distribution. The predictive ROC (receiver operating characteristic) curves were generated using the metabolites with AUC (area under curve) $>0.8$ and $p<0.01$. Afterward, the biochemical databases including HMDB (http:/ /www.hmdb.ca/), 
METLIN (http:/ / metlin.scripps.edu/), MetaboAnalyst (http:/ /www.metaboanalyst.ca/), and KEGG (http:/ / www.kegg.com/) were applied to further identify the biomarkers by either referring the chemical standards or comparing the MS/MS fragmentation patterns. $[\mathrm{M}+\mathrm{H}]^{+}$and $[\mathrm{M}+\mathrm{Na}]^{+}$in ESI+, $[\mathrm{M}-\mathrm{H}]^{-}$and $[\mathrm{M}+\mathrm{FA}-\mathrm{H}]^{-}$in ESI-, were used as the adducts with the mass tolerance at $10 \mathrm{ppm}$.

Finally, MetaboAnalyst 4.0 software was used to filter out the most vital potential metabolic pathways (impact-value threshold above 0.10 ) by analyzing the confirmed distinct metabolites.

\section{Conclusions}

In this paper, a total of 24 amino acid derivatives, including 20 new along with 4 known compounds of pyxinol and ocotillol were synthesized and evaluated in vitro and in vivo for the anti-hepatocarcinoma effect. Most of the amino acid derivatives showed obvious enhanced activity compared with pyxinol or ocotillol. Compound 2e displayed excellent activity in HepG2 human cancer cell and in H22 tumor-bearing mice. It was also revealed that compound $\mathbf{2 e}$ combined with cyclophosphamide (CTX) had the best antitumor activity and the lowest toxicity in mice. A total of 21 potential metabolites involved in 8 metabolic pathways were identified in anti- hepatocarcinoma effect of compound $2 \mathbf{e}$. These results suggest that compound $\mathbf{2} \mathbf{e}$ is a promising agent for anti-hepatocarcinoma with low toxicity, and that it also could increase CTX's efficiency and reduce its toxicity.

Author Contributions: Methodology, J.L. (Junli Liu) and H.Y.; software, Y.L. and L.L.; supervision, J.L. (Jinping Liu) and P.L.; data curation, Y.Z., C.W. and S.F.; investigation, L.T. and B.Z.; writingoriginal draft, Y.Z., H.Y. and J.L. (Jinping Liu) All authors have read and agreed to the published version of the manuscript.

Funding: This research was funded by Young and Middle-aged Technology Innovation Leading Talents and Teams (Grant No. 20200301002RQ), and the Special Project of Industrial Independent Innovation Ability of Jilin Province (Grant No. 2020C038-3), Supported by Graduate Innovation Fund of Jilin University (Grant No. 101832020CX315).

Institutional Review Board Statement: The study was conducted ac-cording to the guidelines of the Declaration of Helsinki, and approved by the Ethics Committee of Animal Experimental Ethics Committee, School of Pharmaceutical Sciences, Jilin University. (protocol code 20190052 and date of approv-26.03.2019).

Data Availability Statement: The data presented in this study are available on request from the corresponding author.

Conflicts of Interest: The authors declare no conflict of interest.

Sample Availability: Samples of the compounds are available from the authors.

\section{References}

1. Liu, Z.; Suo, C.; Mao, X.; Jiang, Y.; Jin, L.; Zhang, T.; Chen, X. Global incidence trends in primary liver cancer by age at diagnosis, sex, region, and etiology, 1990-2017. Cancer 2020, 126, 2267-2278. [CrossRef]

2. New Global Cancer Data: GLOBOCAN 2018/ UICC. Available online: https:/ /www.uicc.org/new-global-cancer-data-globocan (accessed on 22 November 2020).

3. Yang, J.D.; Hainaut, P.; Gores, G.J.; Amadou, A.; Plymoth, A.; Roberts, L.R. A global view of hepatocellular carcinoma: Trends, risk, prevention and management. Nature reviews. Gastroenterol. Hepatol. 2019, 16, 589-604.

4. Liu, H.S.; Pan, C.E.; Yang, W.; Liu, X.M. Antitumor and immunomodulatory activity of resveratrol on experimentally implanted tumor of H22 in Balb/c mice. World J. Gastroenterol. 2003, 9, 1474-1476. [CrossRef] [PubMed]

5. Quan, L.H.; Min, J.W.; Yang, D.U.; Kim, Y.J.; Yang, D.-C. Enzymatic biotransformation of ginsenoside Rb1 to 20 (S)-Rg3 by recombinant $\beta$-glucosidase from Microbacterium esteraromaticum. Appl. Microbiol. Biotechnol. 2012, 94, 377-384. [CrossRef] [PubMed]

6. Bae, E.A.; Han, M.J.; Kim, E.J.; Kim, D.H. Transformation of ginseng saponins to ginsenoside Rh2 by acids and human intestinal bacteria and biological activities of their transformants. Arch. Pharmacal Res. 2004, 27, 61-67. [CrossRef] [PubMed]

7. Liu, X.; Ye, B.; Wu, Y.; Lin, Z.; Zhao, Y.; Piao, H. Synthesis and anti-tumor evaluation of panaxadiol derivatives. Eur. J. Med. Chem. 2011, 46, 1997-2002. [CrossRef] 
8. Lin, X.H.; Cao, M.N.; He, W.N.; Yu, S.W.; Guo, D.A.; Ye, M. Biotransformation of 20 (R)-panaxadiol by the fungus Rhizopus chinensis. Phytochemistry 2014, 105, 129-134. [CrossRef]

9. Mann, J. Natural products in cancer chemotherapy: Past, present and future. Nat. Rev. Cancer 2002, 2, 143-148. [CrossRef]

10. Chikara, S.; Nagaprashantha, L.D.; Singhal, J.; Horne, D.; Awasthi, S.; Singhal, S.S. Oxidative stress and dietary phytochemicals: Role in cancer chemoprevention and treatment. Cancer Lett. 2018, 413, 122-134. [CrossRef]

11. Yang, G.; Gao, M.; Sun, Y.; Wang, C.; Fang, X.; Gao, H.; Diao, W.; Yu, H. Design, synthesis and anti-inflammatory activity of 3-amino acid derivatives of ocotillol-type sapogenins. Eur. J. Med. Chem. 2020, 202, 112507. [CrossRef]

12. Liu, Y.; Ren, Y.; Cao, Y.; Huang, H.; Wu, Q.; Li, W.; Wu, S.; Zhang, J. Discovery of a low toxicity O-GlcNAc transferase (OGT) inhibitor by structure-based virtual screening of natural products. Sci. Rep. 2017, 7, 1-11. [CrossRef] [PubMed]

13. Zhang, Q.H.; Lu, D.; Li, P.Y.; Liu, J.P. Review on the Study of Ocotillol-type Saponins. Ginseng Res. 2011, 4, 47-51.

14. Chen, S.; Staba, E.; Taniyasu, S.; Kasai, R.; Tanaka, O. Further study on dammarane-saponins of leaves and stems of American ginseng, Panax quinquefolium. Planta Med. 1981, 42, 406-409. [CrossRef]

15. Yosioka, I.; Yamauchi, H.; Kitagawa, I. Lichen triterpenoids. V. On the neutral triterpenoids of Pyxine endochrysina nyl. Chem. Pharm. Bull. 1972, 20, 502-513. [CrossRef]

16. Arriaga, F.J.; Rumbero, A.; Wollenweber, E. Three Further Dammarane Type Triterpenes from the Frond Exudate of the Fern Notholaena rigida. Z. Für Nat. C 1996, 51, 750-752. [CrossRef]

17. Pokhilo, N.; Denisenko, V.; Makhan'kov, V.; Uvarova, N. Terpenoids and flavonoids from the leaves of Siberian species of the genus Betula. Chem. Nat. Compd. 1983, 19, 374-375. [CrossRef]

18. Kolak, U.; Kabouche, A.; Öztürk, M.; Kabouche, Z.; Topçu, G.; Ulubelen, A. Antioxidant diterpenoids from the roots of Salvia barrelieri. Phytochem. Anal. 2009, 20, 320-327. [CrossRef]

19. Li, L.; Chen, X.; Li, D.; Zhong, D. Identification of 20(S)-Protopanaxadiol Metabolites in Human Liver Microsomes and Human Hepatocytes. Drug Metab. Dispos. 2011, 39, 472-483. [CrossRef]

20. Atopkina, L.N.; Malinovskaya, G.V.; Elyakov, G.B.; Uvarova, N.I.; Woerdenbag, H.J.; Koulman, A.; Pras, N.; Potier, P. Cytotoxicity of natural ginseng glycosides and semisynthetic analogues. Planta Med. 1999, 65, 30-34. [CrossRef]

21. Prokofeva, N.; Chaikina, E.; Pokhilo, N.; Anisimov, M. Hemolytic and cytotoxic activity of dammarane-type triterpenoids. Chem. Nat. Compd. 2007, 43, 72-75. [CrossRef]

22. Yang, J.; Li, X.; Sun, T.; Gao, Y.; Chen, Y.; Jin, Y.; Li, Y. Semisynthesis and bioactive evaluation of oxidized products from 20(S)ginsenoside Rg3, Rh2, protopanaxadiol (PPD) and their 20(R)-epimers as cytotoxic agents. Steroids 2016, 106, 26-34. [CrossRef] [PubMed]

23. Zhang, Q.; Xu, Y.; Li, H.; Zhao, F.; Wang, C.; Liu, Z.; Liu, P.; Liu, Y.; Meng, Q. Synthesis and in vitro anti-inflammatory activity of C20 epimeric ocotillol-type triterpenes and protopanaxadiol. Planta Med. 2019, 85, 292-301. [CrossRef] [PubMed]

24. Tanaka, O.; Yahara, S. Dammarane saponins of leaves of Panax pseudo-ginseng subsp. himalaicus. Phytochemistry 1978, 17, 1353-1358. [CrossRef]

25. da Silva, K.P.; Pinchin, R.; Pinto, A.D. Phytochemical studies on Brazilian Velloziaceae. II. Triterpenes from Barbacenia flava. Cienc. Cult. 1980, 32, 120-123.

26. Wang, H.; Yu, P.; Bai, J.; Zhang, J.; Kong, L.; Zhang, F.; Du, G.; Pei, S.; Zhang, L.; Jiang, Y.; et al. Ocotillol Enhanced the Antitumor Activity of Doxorubicin via p53-Dependent Apoptosis. Evid. Based Complementary Altern. Med. 2013, 2013, 468537. [CrossRef]

27. Konoshima, T.; Takasaki, M.; Tokuda, H.; Nishino, H.; Duc, N.M.; Kasai, R.; Yamasaki, K. Anti-tumor-promoting Activity of Majonoside-R2 from Veitnamese Ginseng, Panax vietnamensis HA et GRUSHV. Biol. Pharm. Bull. 1998, 21, 834-838. [CrossRef]

28. Tian, J.; Geng, M.; Fu, F. Inhibitory effects of ocotillol on tumor growth in nude mice bearing human ovarian cancer cells. Anticancer Res. 2004, 24, 3653-3654.

29. Liu, N. Studies on Chemical Constituents and Antitumor Activity of Stem and Leaf Saponins Hydrolyzed by Panax Quinceti. Master's Thesis, Yanbian University, Yanji, China, 2008.

30. Lee, S.Y.; Jeong, J.J.; Le, T.H.; Eun, S.H.; Nguyen, M.D.; Park, J.H.; Kim, D.H. Ocotillol, a majonoside R2 metabolite, ameliorates 2, 4, 6-trinitrobenzenesulfonic acid-induced colitis in mice by restoring the balance of Th17/Treg cells. J. Agric. Food Chem. 2015, 63, 7024-7031. [CrossRef]

31. Bi, Y.; Ma, C.; Zhang, H.; Zhou, Z.; Yang, J.; Zhang, Z.; Meng, Q.; Lewis, P.J.; Xu, J. Novel 3-Substituted Ocotillol-Type Triterpenoid Derivatives as Antibacterial Candidates. Chem. Biol. Drug Des. 2014, 84, 489-496. [CrossRef]

32. Liu, J.P. Studies on Isolation, Structure Modification and Pharmacological Activities of Saponins from the Leaves and Stems of Panax Quiquefolium L. Cultivated in China. Ph.D. Thesis, Shenyang Pharmaceutical University, Shenyang, China, 2005.

33. Wang, W.; Wu, X.; Wang, L.; Meng, Q.; Liu, W. Stereoselective Property of 20(S)-Protopanaxadiol Ocotillol Type Epimers Affects Its Absorption and Also the Inhibition of P-Glycoprotein. PLoS ONE 2014, 9, e98887. [CrossRef]

34. Liu, J.; Liu, Y.; Yu, H.; Zhang, Y.; Liu, J. Design, synthesis and biological evaluation of novel pyxinol derivatives with anti-heart failure activity. Biomed. Pharmacother. 2021, 133, 111050. [CrossRef] [PubMed]

35. Li, Z.; Gao, Z.; Gong, A.; Li, X.; Wu, J.; Zhang, L.; Yu, S.; Geng, C. Pharmacokinetic Study of Ocotillol in Rats by LC-MS/MS. Chin. Pharm. J. 2018, 53, 749-754.

36. Yan, X.; Li, Z.; Jiang, J.; Ying, Z.; Geng, C. Rat Plasma Protein Binding Rates of Ocotillol Type Ginsenosides. Chin. Pharm. J. 2020, 55, 2029-2035. 
37. Li, Y.; Hu, H.; Li, Z.; Li, R.; Xu, F.; Zhao, C.; An, Y.; Liu, Y.; Wang, Z. Pharmacokinetic Characterizations of Ginsenoside Ocotillol, $\mathrm{RT}_{5}$ and $\mathrm{F}_{11}$, the Promising Agents for Alzheimer's Disease from American Ginseng, in Rats and Beagle Dogs. Pharmacology 2019, 104, 7-20. [CrossRef] [PubMed]

38. Wang, J.; Hu, X.L.; Wen, W.H.; Yang, L.L.; Xu, S.; Zhu, Y.L. Structural modification of natural medicines by amino acids and short peptides. China Mod. Appl. Pharm. 2011, 28, 1095-1100.

39. Landowski, C.P.; Lorenzi, P.L.; Song, X.; Amidon, G.L. Nucleoside ester prodrug substrate specificity of liver carboxylesterase. J. Pharmacol. Exp. Ther. 2006, 316, 572-580. [CrossRef]

40. Vig, B.S.; Huttunen, K.M.; Laine, K.; Rautio, J. Amino acids as promoieties in prodrug design and development. Adv. Drug Deliv. Rev. 2013, 65, 1370-1385. [CrossRef]

41. Diaz-Padilla, I.; Siu, L.L. Brivanib alaninate for cancer. Expert Opin. Investig. Drugs 2011, 20, 577-586. [CrossRef]

42. Kim, M.K.; Park, K.-S.; Yeo, W.-S.; Choo, H.; Chong, Y. In vitro solubility, stability and permeability of novel quercetin-amino acid conjugates. Bioorganic Med. Chem. 2009, 17, 1164-1171. [CrossRef]

43. Suhas, R.; Chandrashekar, S.; Gowda, D.C. Synthesis of uriedo and thiouriedo derivatives of peptide conjugated heterocycles-A new class of promising antimicrobials. Eur. J. Med. Chem. 2012, 48, 179-191. [CrossRef]

44. Vardhan, D.M.S.; Shantharam, C.S.; Suhas, R.; Sridhara, M.B.; Gowda, D.C. Synthesis and SAR studies of urea and thiourea derivatives of Gly/Pro conjugated to piperazine analogue as potential AGE inhibitors. Protein Pept. Lett. 2013, 20 , 888-897. [CrossRef] [PubMed]

45. Fang, L.; Wang, M.; Gou, S.; Liu, X.; Zhang, H.; Cao, F. Combination of amino acid/dipeptide with nitric oxide donating oleanolic acid derivatives as PepT1 targeting antitumor prodrugs. J. Med. Chem. 2014, 57, 1116-1120. [CrossRef] [PubMed]

46. Yuan, W.; Guo, J.; Wang, X.; Su, G.; Zhao, Y. Non-protein amino acid derivatives of 25-methoxylprotopanaxadiol/25hydroxyprotopanaxadioland their anti-tumour activity evaluation. Steroids 2018, 129, 1-8. [CrossRef] [PubMed]

47. Tedesco, L.; Corsetti, G.; Ruocco, C.; Ragni, M.; Rossi, F.; Carruba, M.O.; Valerio, A.; Nisoli, E. A specific amino acid formula prevents alcoholic liver disease in rodents. Am. J. Physiol. Gastrointest. Liver Physiol. 2018, 314, G566-G582. [CrossRef] [PubMed]

48. Meng, Q.G.; Tan, W.J.; Hou, G.G.; Zhang, X.Y.; Hu, X.Y.; Yang, F.; Bai, G.J.; Zhu, W.W.; Cai, Y.; Bi, Y. Synthesis and structural characterization of two epimers driven from 20 (S)-protopanaxadiol. J. Mol. Struct. 2013, 1054, 1-5. [CrossRef]

49. Schmeda-Hirschmann, G.; Rodríguez, J.A.; Theoduloz, C.; Valderrama, J.A. Gastroprotective effect and cytotoxicity of labdeneamides with amino acids. Planta Med. 2011, 77, 340-345. [CrossRef] [PubMed]

50. Hayaishi, S.; Chung, H.; Kudo, M.; Ishikawa, E.; Takita, M.; Ueda, T.; Kitai, S.; Inoue, T.; Yada, N.; Hagiwara, S. Oral branchedchain amino acid granules reduce the incidence of hepatocellular carcinoma and improve event-free survival in patients with liver cirrhosis. Dig. Dis. 2011, 29, 326-332. [CrossRef]

51. Ma, L.; Wang, X.; Li, W.; Qu, F.; Liu, Y.; Lu, J.; Su, G.; Zhao, Y. Conjugation of Ginsenoside with Dietary Amino Acids: A Promising Strategy to Suppress Cell Proliferation and Induce Apoptosis in Activated Hepatic Stellate Cells (Article). J. Agric. Food Chem. 2019, 67, 10245-10255. [CrossRef]

52. Wang, K.Y.; Zhou, Z.W.; Zhang, H.Y.; Cao, Y.C.; Xu, J.Y.; Ma, C.; Meng, Q.G.; Bi, Y. Design, Synthesis and Antibacterial Evaluation of 3-Substituted Ocotillol-Type Derivatives. Molecules. 2018, 23, 3320. [CrossRef]

53. Zhou, Z.; Ma, C.; Zhang, H.; Bi, Y.; Chen, X.; Tian, H.; Xie, X.; Meng, Q.; Lewis, P.J.; Xu, J. Synthesis and biological evaluation of novel ocotillol-type triterpenoid derivatives as antibacterial agents. Eur. J. Med. Chem. 2013, 68, 444-453. [CrossRef]

54. Duan, L.Z. The Semisynthesis of 20(S)-PPD Derivatives and Screening of its Antitumor Activity in Vitro. Master's Thesis, Fudan University, Shanghai, China, 2014.

55. Bi, Y.; Liu, X.-X.; Zhang, H.-Y.; Yang, X.; Liu, Z.-Y.; Lu, J.; Lewis, P.J.; Wang, C.-Z.; Xu, J.-Y.; Meng, Q.-G. Synthesis and antibacterial evaluation of novel 3-substituted ocotillol-type derivatives as leads. Molecules 2017, 22, 590. [CrossRef] [PubMed]

56. Sun, Y.; Fang, X.; Gao, M.; Wang, C.; Gao, H.; Bi, W.; Tang, H.; Cui, Y.; Zhang, L.; Fan, H.; et al. Synthesis and Structure-Activity Relationship of Pyxinol Derivatives as Novel Anti-Inflammatory Agents. ACS Med. Chem. Lett. 2020, 11, 457-463. [CrossRef] [PubMed]

57. Ren, Q.; Yang, G.; Guo, M.; Guo, J.; Li, Y.; Lu, J.; Yang, Q.; Tang, H.; Li, Y.; Fang, X.; et al. Design, synthesis, and discovery of ocotillol-type amide derivatives as orally available modulators of P-glycoprotein-mediated multidrug resistance. Eur. J. Med. Chem. 2019, 161, 118-130. [CrossRef] [PubMed]

58. Holeček, M.; Vodeničarovová, M. Muscle wasting and branched-chain amino acid, alpha-ketoglutarate, and ATP depletion in a rat model of liver cirrhosis. Int. J. Exp. Pathol. 2018, 99, 274-281. [CrossRef]

59. Kuwahata, M.; Kubota, H.; Kanouchi, H.; Ito, S.; Ogawa, A.; Kobayashi, Y.; Kido, Y. Supplementation with branched-chain amino acids attenuates hepatic apoptosis in rats with chronic liver disease. Nutrres 2012, 32, 522-529. [CrossRef]

60. Barakat, H.A.; Hamza, A.H. Glycine alleviates liver injury induced by deficiency in methionine and or choline in rats. Eur. Rev. Med. Pharmacol. Sci. 2012, 16, 72.

61. Heidari, R.; Mohammadi, H.; Ghanbarinejad, V.; Ahmadi, A.; Ommati, M.M.; Niknahad, H.; Jamshidzadeh, A.; Azarpira, N.; Abdoli, N. Proline supplementation mitigates the early stage of liver injury in bile duct ligated rats. J. Basic Clin. Physiol. Pharmacol. 2018, 30, 91-101. [CrossRef]

62. Qin, X.Y.; Lu, J.; Cai, M.; Kojima, S. Arachidonic acid suppresses hepatic cell growth through ROS-mediated activation of transglutaminase. FEBS Open Bio 2018, 8, 1703-1710. [CrossRef] 
63. Zhou, L.A.; Ding, L.B.; Yin, P.A.; Lu, X.A.; Wang, X.B.; Niu, J.B.; Gao, P.B.; Xu, G.A. Serum metabolic profiling study of hepatocellular carcinoma infected with hepatitis B or hepatitis $C$ virus by using liquid chromatography-mass spectrometry. $J$. Proteome Res. 2012, 11, 5433-5442. [CrossRef]

64. Panigrahy, D.; Greene, E.R.; Pozzi, A.; Wang, D.W.; Zeldin, D.C. EET signaling in cancer. Cancer Metastasis Rev. 2011, 30, 525-540. [CrossRef]

65. Soumya, S.J.; Binu, S.; Helen, A.; Reddanna, P.; Sudhakaran, P.R. 15-LOX metabolites and angiogenesis: Angiostatic effect of 15(S)-HPETE involves induction of apoptosis in adipose endothelial cells. Peer] 2014, 2, e635. [CrossRef] [PubMed]

66. Soumya, S.J.; Binu, S.; Helen, A.; Anil Kumar, K.; Reddanna, P.; Sudhakaran, P.R. Effect of 15-lipoxygenase metabolites on angiogenesis: 15(S)-HPETE is angiostatic and 15(S)-HETE is angiogenic. Inflamm. Res. 2012, 61, 707-718. [CrossRef] [PubMed]

67. Zhang, X. Promoter Activity and Regulation of Human CYP4F2 LTB (4) Omega-Hydroxylase Gene in HEPG2 Cells. Ph.D. Thesis, Kent State University, St. Kent, OH, USA, 2000.

68. Honn, K.V.; Meyer, J. Thromboxanes and prostacyclin: Positive and negative modulators of tumor growth. Biochem. Biophys. Res. Commun. 1981, 102, 1122-1129. [CrossRef]

69. Kurabe, N.; Hayasaka, T.; Ogawa, M.; Masaki, N.; Ide, Y.; Waki, M.; Nakamura, T.; Kurachi, K.; Kahyo, T.; Shinmura, K.; et al. Accumulated phosphatidylcholine (16:0/16:1) in human colorectal cancer; possible involvement of LPCAT4. Cancer Sci. 2013, 104, 1295-1302. [CrossRef]

70. He, Q.; Takizawa, Y.; Hayasaka, T.; Masaki, N.; Kusama, Y.; Su, J.; Mineta, H.; Setou, M. Increased phosphatidylcholine (16:0/16:0) in the folliculus lymphaticus of Warthin tumor. Anal. Bioanal. Chem. 2014, 406, 5815-5825. [CrossRef]

71. Kim, D.; Lee, Y.; Lee, Y.; Oh, S.; Yun, Y.; Yoo, H. Elevation of sphingoid base 1-Phosphate as a potential contributor to hepatotoxicity in Fumonisin B1-exposed mice. Arch. Pharmacal Res. 2007, 30, 962-969. [CrossRef]

72. Jin, J.; Liao, W.; Yao, W.; Zhu, R.; Li, Y.; He, S. Aldo-keto Reductase Family 1 Member B 10 Mediates Liver Cancer Cell Proliferation through Sphingosine-1-Phosphate. Sci. Rep. 2016, 2, IJTR-S2129. [CrossRef]

73. Okuno, M.; Kato, M.; Kanai, M.; Muto, Y. Determination of cellular retinol-binding protein in human hepatocellular and colorectal carcinomas by radioimmunoassay. J. Gastroenterol. Hepatol. 1987, 2, 397-406. [CrossRef]

74. Idres, N.; Benoit, G.; Flexor, M.A.; Lanotte, M.; Chabot, G.G. Granulocytic differentiation of human NB4 promyelocytic leukemia cells induced by all-trans retinoic acid metabolites. Cancer Res. 2001, 61, 700-705.

75. Xie, R.; Li, Z.; Chen, P.; Zhou, X. Bufothionine induced the mitochondria-mediated apoptosis in H22 liver tumor and acute liver injury. Chin. Med. 2015, 10, 1-11. [CrossRef]

76. Richard, D.M.; Dawes, M.A.; Mathias, C.W.; Acheson, A.; Hill-Kapturczak, N.; Dougherty, D.M. L-Tryptophan: Basic Metabolic Functions, Behavioral Research and Therapeutic Indications. Intj. Tryptophan Res. 2009, 2, 45-60. [CrossRef] [PubMed]

77. Stratakis, N.; Conti, D.; Jin, R.; Margetaki, K.; Valvi, D.; Siskos, A.P.; Maitre, L.; Garcia, E.; Varo, N.; Zhao, Y.; et al. Prenatal Exposure to Perfluoroalkyl Substances Associated with Increased Susceptibility to Liver Injury in Children. Hepatology (Baltim. Md.) 2020, 72, 1758-1770. [CrossRef] [PubMed]

78. Deng, P.; Barney, J.; Petriello, M.C.; Morris, A.J.; Wahlang, B.; Hennig, B. Hepatic metabolomics reveals that liver injury increases PCB 126-induced oxidative stress and metabolic dysfunction. Chemosphere 2019, 217, 140-149. [CrossRef] [PubMed]

79. Kwee, S.A.; Franke, A.A.; Custer, L.J.; Li, X.; Wong, L.L. Fatty acid and phospholipid profiling of liver tumor tissue: Correlation with in vivo molecular PET imaging of phosphocholine synthesis. Cancer Res. 2015, 75, 1486. [CrossRef]

80. Pan, P.; Skaer, C.W.; Wang, H.; Kreiser, M.A.; Stirdivant, S.M.; Oshima, K.; Huang, Y.; Young, M.R.; Wang, L. Systemic Metabolite Changes in Wild-type C57BL/6 Mice Fed Black Raspberries. Nutr. Cancer 2017, 69, 299-306. [CrossRef]

81. Tang, J.; Tao, Z.; Wen, D. miR-612 suppresses the stemness of liver cancer via Wnt/beta-catenin signaling. Biochem. Biophys. Res. Commun. 2014, 447, 210-215. [CrossRef] 